\title{
The Turkish Adaptation of Implicit Theory of Intelligence Scale: The Validity and Reliability Study
}

\author{
Mustafa ÍLHAN ${ }^{1, *}$ and Bayram ÇETİN ${ }^{2}$ \\ ${ }^{1}$ Dicle University, Diyarbakır, TURKEY; ${ }^{2}$ Gaziantep University, Gaziantep, \\ TURKEY
}

Received: 05.11.2012

Accepted: 10.05 .2013

\begin{abstract}
The purpose of this study is to adapt the Implicit Theory of Intelligence Scale (ITIS) by Abd-ElFattah and Yates (2006) to Turkish and to investigate its psychometric properties. The study was conducted on four different samples which consisted of 689 students who studied different subjects at the Ziya Gokalp Faculty of Education, Dicle University, during the Fall Term of the 2012-2013 Academic Year. The findings on the linguistic equivalence indicated that the correlation between the items included in the Turkish and original form varied between .81 and .96 . The factor analysis concluded that the Turkish version had a two-factor structure in parallel with the original one. As for the concurrent validity, the calculation of correlation between the ITIS and AGOS reported findings similar to the ones in the literature. The reliability coefficients were over .70 for both the entity theory and incremental theory. The item analysis reported that the corrected item total correlations ranged from .33 and .63 and the differences between the top and bottom $27 \%$ groups were significant for all the items included in the scale. All these findings suggest that the Turkish version of the ITIS is a valid and reliable instrument that can be used to measure university students' beliefs about intelligence.
\end{abstract}

Key words: Implicit Theory of Intelligence, Implicit Theory of Intelligence Scale, Validity, Reliability DOI No: http://dx.doi.org/10.12973/nefmed159

\section{Summary}

\section{Introduction}

Conceived by Dweck (1986), implicit theories of intelligence explain individuals' beliefs about intelligence. They are based on two conflicting views about intelligence. The first one is the entity theory based on the assumption that intelligence is determined by one's genetic codes. Those subscribing to the entity theory maintain that intelligence is fixed and thus cannot be changed. The other belief is the incremental theory, which holds that intelligence can be improved though individual efforts. The advocates of this belief assert that

\footnotetext{
* Corresponding Author: Research Assistant Mustafa İLHAN, Dicle University, Ziya Gökalp Faculty of Education, Primary Education Department, Diyarbakır, TURKEY.

E-mail: mustafailhan21@gmail.com
} 
people are born with a blank mind and interact with the environment influences the development of intelligence. Whether students endorse the entity theory or the incremental theory influences their academic accomplishments, tendencies to success, motivation, test anxiety and determination to cope with academic difficulties, thus playing a key role in the efforts they make during the instructional process. It is quite important to identify their beliefs about intelligence, since the extent which they adopt either theory has an effect on their cognitive and affective properties. A review of literature suggests that there is no measuring instrument that can be used to measure individuals' beliefs about intelligence on Turkish culture, which means that designing one will make a great contribution to the literature. In this context, the purpose of this study is to adapt the Implicit Theory of Intelligence Scale (ITIS) by Abd-El-Fattah and Yates (2006) to Turkish.

\section{Methodology}

For validity and reliability purposes, the ITIS was implemented on four different samples which consisted of 689 students who studied different subjects at the Ziya Gokalp Faculty of Education, Dicle University, during the Fall Term of the 2012-2013 Academic Year. The data were collected not only through the ITIS but also via the Achievement Goals Orientations Scale (AGOS) developed by Akin and Cetin (2007). Prior to the process, Greg Yates was emailed and informed consent was obtained from him to adapt the scale into Turkish. Next, the scale, which was in English, was translated into Turkish by two linguists specializing in English and three educational specialists with a good command of English. Then, they were compared so that Turkish statements representing the original ones in the best way could be chosen. Afterwards, the Turkish and English versions were compared and revised by two lecturers specializing in educational sciences. They held discussions over the controversial items in the translated version, which resulted in the agreed-upon final form. The correlation between the scores in the Turkish and English forms was calculated in order to reveal the degree of consistency between the two. It was concluded that the linguistic equivalence had been ensured. In addition, the scale was tested for construct and concurrent validity purposes. An exploratory factor analysis and confirmatory factor analysis were conducted on the scale to reveal construct validity. The correlation between the ITIS and AGOS was calculated so that the concurrent validity could be identified. On the other hand, the reliability of the ITIS was tested through such coefficients as internal consistency, splithalf and test retest. The item discrimination of the ITIS was calculated through the corrected 
item total correlation and a comparison between the top and bottom $27 \%$ groups. The validity and reliability analyzes were carried out with SPSS 20.0 and AMOS 20.0.

\section{Results}

The findings on the linguistic equivalence indicated that the correlation between the items included in the Turkish and original form varied between .81 and .96 . The exploratory and confirmatory factor analyzes concluded that the Turkish version had a two-factor structure in parallel with the original one. As for the concurrent validity, the calculation of the correlation between the ITIS and AGOS reported findings similar to the ones in the literature. The reliability analysis showed that the internal consistency coefficients were .81 and .71 for the entity theory and incremental theory respectively. On the other hand, the split-half coefficients .83 and .71 for an entity theory and incremental theory respectively whereas the test retest coefficients were .95 and .90 for the entity theory and incremental theory respectively. The item analysis concluded that the corrected item total correlations ranged from .33 and .63 and the differences between the top and bottom $27 \%$ groups were significant for all the items included in the scale.

\section{Discussion}

All the findings on the validity, reliability and item analysis suggest that the Turkish version of the ITIS is a valid and reliable instrument that can be used to measure university students' beliefs about intelligence. In other words, the present study served its purpose and yielded an instrument with enough psychometric properties to measure individuals' beliefs about the nature of intelligence. Even so, the group of participants was confined to university students, which might mean that the validity was proven only on university students. Therefore, it is essential that the validity and reliability of the Turkish version should be tested on different samples.

The correlation between the ITIS and AGOS was calculated so that the concurrent validity could be identified. A review of literature on implicit theories of intelligence suggests that individuals' beliefs about intelligence have an influence on their achievement goal orientations as well as their approaches to learning, test anxiety, sources of motivation and risk-taking behaviors. Accordingly, further studies could be conducted on the correlation between the ITIS and approaches to learning, text anxiety, motivation and academic risktaking behaviors. Hopefully, such studies will also make great contributions to the extent to which the ITIS measure what is intended. 


\title{
Örtük Zeka Teorisi Ölçeğinin Türkçe Uyarlaması: Geçerlik ve Güvenirlik Çalışması
}

\author{
Mustafa ÍLHAN $^{1, *}$ ve Bayram ÇETÍN ${ }^{2}$ \\ ${ }^{1}$ Dicle Üniversitesi, Diyarbakır, TÜRKIYYE; ${ }^{2}$ Gaziantep Üniversitesi, \\ Gaziantep, TÜRKİYE
}

Makale Gönderme Tarihi: 05.11.2012

Makale Kabul Tarihi: 10.05 .2013

\begin{abstract}
Özet - Bu araştırmada, Abd-El-Fattah ve Yates (2006) tarafından geliştirilen Örtük Zekâ Teorisi Ölçeği’nin (ÖZTÖ) Türkçe'ye uyarlanması ve ölçeğin psikometrik özelliklerinin incelenmesi amaçlanmıştır. Araştırma 2012-2013 Öğretim Y1lı Güz Dönemi'nde Dicle Üniversitesi Ziya Gökalp Eğitim Fakültesi'nin farklı bölümlerinde öğrenim gören ve toplam 689 öğrenciden oluşan 4 ayrı çalışma grubu üzerinde yürütülmüştür. Dilsel eşdeğerlik çalı̧̧masında, ÖZTÖ'nün Türkçe ve İngilizce formlarında bulunan maddeler arasındaki korelasyon katsayıları .81 ile .96 arasında bulunmuştur. Faktör analizi sonucunda, ÖZTÖ’nün Türkçe formunun orijinal forma paralel iki faktörlü bir yapıya sahip olduğu ortaya çıkmıştır. Uyum geçerliği kapsamında, ÖZTÖ ile Başarı Yönelimleri Ölçeği arasındaki korelasyon hesaplanmış ve örtük zekaya ilişkin literatür ile örtüşen bulgular elde edilmiştir. ÖZTÖ'de yer alan varlık teorisi ve artımsal teori alt ölçekleri için hesaplanan güvenirlik katsayılarının .70 'in üzerinde olduğu saptanmıştır. Madde analizi sonucunda, düzeltilmiş madde toplam korelasyonlarının .33 ile .63 arasında değiştiği ve \%27'lik alt-üst grupların ortalamaları arasındaki farkların ölçekte yer alan tüm maddeler için anlamlı olduğu belirlenmiştir. Bu sonuçlar, ÖZTÖ’nün Türkçe formunun üniversite öğrencilerinin zekâya yönelik inançlarını ölçmek amacıyla kullanılabilecek geçerli ve güvenilir bir ölçme aracı olduğunu göstermektedir.
\end{abstract}

Anahtar kelimeler: Örtük Zeka Teorisi, Örtük Zeka Teorisi Ölçeği, Geçerlik, Güvenirlik

\section{Giriş}

İnançlar; bireyin tecrübeleri aracılığıyla şekillenen (Nespor, 1987; Pajares, 1992) tutum, davranış (Hazır Bıkmaz, 2002; Mansour, 2009; Olson, Roese, \& Zanna, 1996; Öztuna Kaplan ve Macaroğlu Akgül, 2009; Pintrich \& Schunk, 2002) ve zihinsel süreçlerini etkileyen (Schommer, 1998) yaşamda karşılaştı̆̆ı her türlü olay, olgu, kişi ya da nesneyi nasıl algıladığını, anlamlandırdığııı, ona karşı nasıl davrandığını belirleyen (Deryakulu, 2006; Fishbein \& Ajzen, 1975; Pajares, 1992) ve birey tarafından kuşku duyulmaksızın doğru olarak kabul edilen (Deryakulu, 2006; Koballa \& Crowley, 1985; Krows, 1999) içsel kabuller ya da

\footnotetext{
* İletişim: Arş. Gör. Mustafa İLHAN, Dicle Üniversitesi, Ziya Gökalp Eğitim Fakültesi, İlköğretim Bölümü, Diyarbakır, Türkiye.

E-mail: mustafailhan21@gmail.com
} 
önermeler şeklinde tanımlanmaktadır (Deryakulu, 2004; Oliver \& Koballa, 1992; Richardson, 2003). İnançların bireylerin düşünce ve davranışları üzerinde sahip olduğu bu güçlü belirleyici etki eğitimcilerin öz yeterlilik inanc1, epistemolojik inanç, öğrenmeye yönelik inanç gibi birçok farklı inancı öğrenme ve öğretme süreçleri açısından dikkate almalarını zorunlu k1lmaktadır (Chan, 2004; Deryakulu, 2006). Öğrenme-öğretme sürecinde dikkate alınması gereken inançlardan biri de bireylerin zekânın doğası hakkında sahip oldukları inançlardır (Garcia-Cepero \& McCoach, 2009).

Dweck (1986), bireylerin zekâya yönelik inançlarını açıklamak üzere örtük zekâ teorisini ortaya atmıştır. Örtük zekâ teorisi, zekâ ile ilgili iki zıt inanç üzerine yapılandırılmıştır (Braten \& Strømsø, 2004; Dupeyrat \& Mariné, 2005; Plaks, Grant \& Dweck, 2005). Bu inançlardan ilki, zekânın bireyin genetik kodlarıyla belirlenen bir özellik olduğu esasına dayanan varlık teorisidir (Cadwallader, 2009). Varlık teorisini (Entity Theory) benimseyen bireyler, zekânın sabit ve değiştirilemez bir özellik olduğuna inanmaktadırlar (Ahmavaara \& Houston, 2007; Gervey, Chiu, Hong \& Dweck, 1999). Örtük zekâ teorisi kapsamında yer alan bir diğer inanç ise zekânın bireysel çabalar ile geliştirilebilen bir özellik olduğunu kabul eden artımsal teoridir (Blackwell, Trzesniewski, \& Dweck, 2007; Dweck, 1999; Elliot \& Church, 1997; Kennett \& Keefer, 2006). Artımsal teoriyi (Incremental Theory) benimseyen bireyler, insanın boş bir yazı tahtası gibi dünyaya geldiğine ve çevre ile girilen etkileşimin zekânın gelişimi üzerinde belirleyici olduğuna inanmaktadırlar. Öğrencilerin varlık teorisi ve artımsal teoriden hangisini ne düzeyde benimsedikleri, akademik başarılarını (Aronson, Fried, \& Good, 2002; Blackwell, Trzesniewski \& Dweck, 2007; Da Fonseca, Cury, Bailly, \& Rufo, 2004; Good, Aronson \& Inzlicht, 2003), ögrenme stratejilerini (Dahl, Bals \& Turi, 2005; Stipek \& Gralinski, 1996; Vermetten, Lodewijks \& Vermunt, 2005), başarı yönelimlerini (Ablard, 2002; Dweck, 1999; Dweck \& Leggett, 1988; Dweck \& Molden, 2005; Mueller \& Dweck, 1998; Sorich-Blackwell, 2001; Vandewalle, 1997), motivasyonlarını (Carr \& Dweck 2011; Dweck, 1986), sınav kaygılarını (Cury, Elliot, Da Fonseca, \& Moller, 2006; Dweck \& Sorich, 1999; Stipek \& Gralinski, 1996), akademik güçlüklerle mücadele etme konusundaki kararlılıklarını (Henderson \& Dweck, 1990; Leondari \& Gialamas, 2002) etkilemekte ve öğrenme sürecinde ortaya koydukları çaba üzerinde belirleyici rol oynamaktadır (Dupeyrat \& Mariné, 2005).

Zekâ ile ilgili varlık teorisini benimseyen ve zekânın sabit bir özellik olduğuna inanan öğrenciler; 
- Performans yönelimlidirler. Bu öğrenciler başkalarına kendi yeterliliklerini göstermek için çalışır (Braten \& Strømsø, 2004), kendilerini diğer öğrenciler ile karş1laştırmakla ilgilenir (Delavar, Ahadi \& Barzegar, 2011) ve başarı ölçütü olarak sosyal karşılaştırmaları kullanırlar (Ames, 1992; Ames \& Archer,1998).

- Bir işi başarıyla tamamlayarak yeteneklerini ve zekâlarını başkalarına göstermek istediklerinden, kolay ve hızlı bir şekilde tamamlanabilen işlere taliptirler (Dweck \& Leggett, 1988; Roedel \& Schraw, 1995). Düşük bir performans gösterme riski olan zorlu görevlerden kaçınırlar (Dweck \& Leggett, 1988). Güçlüklerle karşı karşıya geldiklerinde kolayca vazgeçme eğilimindedirler (Dupeyrat \& Mariné, 2005).

- Öğrenme sürecinde karşılaştıkları başarısızlıkları aşılması gereken engeller olarak görürler (García-Cepero \& McCoach, 2009; Lee, 1996).

- Zorluklar karşısında kendilerini çaresiz hissederler (Diener \& Dweck, 1980; Goetz \& Dweck, 1980; Henderson \& Dweck, 1990). Bir hata yaptıklarında direnmeyip geri çekilme olasılıkları yüksektir (Chiu, Hong \& Dweck, 1997).

- Yaşadıkları başarısızlıkların nedenlerini kendi yeteneklerinde arama eğilimindedirler (Delavar, Ahadi \& Barzegar, 2011; Henderson \& Dweck, 1990; Hong, Chiu, Dweck, Lin, \& Wan, 1999; Ziegler, Schober \& Dresel, 2005). Karşılaştıkları olumsuz durumlarda kendilerini suçlar ve yaşadıkları başarısızlıkları zekâ düzeylerinin düşük olmasına bağlarlar (Dweck, Chiu \& Hong, 1995; Dweck, Hong \& Chiu 1993; Dweck \& Master, 2008; Hong, Chiu, \& Dweck, 1995).

- Öğrenme sürecinde, yalnızca hafızadan geri çağırmayı gerektiren bilgi düzeyindeki davranışların öğrenilmesinde etkili olan (Stump, Husman, Chung \& Done, 2009) yüzeysel öğrenme stratejilerini kullanırlar (Stipek \& Gralinski, 1996; Vermetten, Lodewijks \& Vermunt, 2005).

Zekâ ile ilgili artımsal teoriyi benimseyen ve zekânın bireysel çabalar ile arttırılabilen bir özellik olduğuna inanan öğrenciler ise;

- Öğrenme yönelimlidirler (Dweck, 1991). Yeni bilgi ve beceriler kazanmak ve yeteneklerini geliştirmek için çalışırlar (Ames, 1992; Ames \& Archer,1998; Braten \& Strømsø, 2004; Dupeyrat \& Mariné, 2005).

- Öğrenmeye teşvik eden zorlu ve güç görevler konusunda isteklidirler (Dweck, 1999; Dweck \& Molden, 2005). Güç görevlerle karşı karşıya geldiklerinde varlık teorisini benimseyen akranlarına göre daha az kaygı yaşarlar (Hong, Dweck, \& Chiu, 1999). 
- Zorlu durumlarla karşılaştıklarında akranlarına göre daha fazla çaba ortaya koyma eğilimindedirler (Mangels, Butterfield, Lamb, Good \& Dweck, 2006).

- Öğrenme sürecinde karşılaştıkları başarısılıkları, öğrenme ve zekâlarını geliştirme için bir firsat olarak görürler (Hong, Chiu, Dweck, Lin \& Wan, 1999).

- Zorluklara karşı sebat etme konusunda isteklidirler (Allison \& Urdan, 1993; Ames, 1990; Dweck \& Master, 2008).

- Öğrenmeye ilişkin hedeflerini gerçekleştirmek için not tutma, yorumlama, özet çıkarma, soru-cevap gibi derin öğrenme stratejilerini işe koşarlar (Dahl, Bals \& Turi, 2005; Husman, Hilpert, Stump \& Lynch, 2009; Pressley \& Harris, 2006).

- Yaşadıkları başarısızlıkların nedenlerini etkili olmayan çalışma yöntemlerine ve ortaya koydukları çabanın yeterli olmayışına bağlarlar (Delavar, Ahadi \& Barzegar, 2011; Roedel \& Schraw, 1995).

Bireylerin örtük zekâ teorisi kapsamında yer alan varlık teorisi ve artımsal teoriden hangisini ne düzeyde benimsedikleri bilişsel ve duyuşsal özelliklerini etkilediğinden (GarciaCepero \& McCoach, 2009; Spinath, Spinath, Riemann \& Angleitner, 2003) zekâ ile ilgili inançların tespiti önem kazanmaktadır. Alanyazın incelendiğinde, Türk kültüründe bireylerin zekâya yönelik inançlarını ölçmek amacıyla kullanılabilecek bir ölçme aracına rastlanmamıştır. Dolayısıyla bireylerin zekânın doğası hakkında sahip oldukları inançları ölçmek amacıyla kullanılabilecek bir ölçeğin Türk kültürüne kazandırılması önem arz etmektedir. Bu kapsamda araştırmada, Abd-El-Fattah ve Yates (2006) tarafından geliştirilen Örtük Zekâ Teorisi Ölçeği'nin (ÖZTÖ) Türkçe’ye uyarlanması amaçlanmaktadır. ÖZTÖ’nün psikometrik özelliklerinin faklı kültürlerden (Avusturya ve Mısır) katılımcılardan oluşan bir çalışma grubu üzerinde incelenmiş olması, literatürde mevcut olan örtük zekâ teorisi ölçeklerinden (Abd-El-Fattah \& Yates, 2006; Da Fonseca, Schiano-Lomoriello, Cury, Poinso, Rufo \& Therme, 2007; Dweck, 1999; Dweck \& Henderson 1989; Stipek \& Gralinski, 1996) hangisinin Türkçe'ye uyarlanmasının daha uygun olacağı konusunda araştırmacıların karar vermesine yardımcı olmuştur. ÖZTÖ’nün 5 dakika gibi kısa bir sürede uygulanabilen kullanışlı bir ölçme aracı olması, araştırmacıların ÖZTÖ’yü Türkçe'ye uyarlama konusundaki kararlarını etkileyen bir diğer faktördür. 


\section{Yöntem}

Örneklem

ÖZTÖ’nün geçerlik ve güvenirlik çalışmaları 2012-2013 Öğretim Yılı Güz Dönemi'nde Dicle Üniversitesi Ziya Gökalp Eğitim Fakültesi'nin farklı bölümlerinde öğrenim gören, farklı sınıf düzeylerinden toplam 689 öğrenciden oluşan 4 ayrı çalışma grubu üzerinde yürütülmüştür. Birinci çalışma grubu, İngilizce Öğretmenliği programına kayıtlı 63’ü (\%62.40) bayan ve 38'i (\%37.60) erkek olmak üzere toplam 101 öğrenciden oluşmaktadır. Bu gruptaki öğrencilerin yaşları 17 ile 39 arasında değişmekte olup grubun yaş ortalaması 21.05 'dir. Ölçeğin dilsel eş değerlik analizi bu gruptan elde edilen veriler üzerinden gerçekleştirilmiştir. İkinci çalışma grubu, İlköğretim Matematik Öğretmenliği ( $\mathrm{n}=43$, \%10.40), Okul Öncesi Öğretmenliği ( $\mathrm{n}=28, \% 6.70)$, Sınıf Öğretmenliği ( $\mathrm{n}=139, \% 33.50)$ ve Sosyal Bilgiler Öğretmenliği ( $\mathrm{n}=205, \% 49.40)$ programlarına kayıtllı 200’ü (\%48.20) bayan, 215'i (\%51.80) erkek olmak üzere toplam 415 öğrenciden oluşmaktadır. Bu gruptaki öğrencilerin yaşları 17 ile 33 arasında değiş̧mekte olup grubun yaş ortalaması 20.98'dir. Ölçeğin yapı geçerliği, iç tutarlılık ve iki yarı güvenirliği ile madde analizleri bu gruptan elde edilen veriler üzerinden gerçekleştirilmiştir. Üçüncü çalışma grubu, Sınıf Öğretmenliği programina kayitlı 31'i bayan (\%43.70) ve 40'1 (\%56.30) erkek olmak üzere toplam 71 öğrenciden oluşmaktadır. Bu grupta yer alan öğrencilerin yaşları 20 ile 27 arasında değişmekte olup grubun yaş ortalaması $22.58^{\prime}$ dir. ÖZTÖ'nün test tekrar test güvenirliği bu gruptan elde edilen veriler üzerinden hesaplanmıştır. Dördüncü çalışma grubu, Sınıf Öğretmenliği (n=64, \%62.70) ve Sosyal Bilgiler Öğretmenliği $(\mathrm{n}=38, \% 37.30)$ programlarına kayıtlı 49’u (\%48) bayan, 53’ü (\%52) erkek olmak üzere toplam 102 öğrenciden oluşmaktadır. Bu gruptaki öğrencilerin yaşları 19 ile 38 arasında değişmekte olup grubun yaş ortalaması 21.98'dir. Uyum geçerliği kapsamında ÖZTÖ ile Başarı Yönelimleri Ölçeği (BYÖ) arasındaki korelasyon bu gruptan elde edilen veriler üzerinden hesaplanmıştır.

Veri Toplama Araçları

Araştırmada veri toplama aracı olarak ÖZTÖ’nün yanı sıra uyum geçerliğinin incelenmesinde BYÖ kullanılmıştır.

Örtük Zekâ Teorisi Ölçeği-ÖZTÖ (Implicit Theory of Intelligence Scale-ITIS)

ÖZTÖ, Abd-El-Fattah ve Yates (2006) tarafindan bireylerin zekânın doğası hakkında sahip oldukları inançları belirlemek amacıyla geliştirilmiş kendini rapor etme (self-report) türünden bir ölçme aracıdır. 4'li likert tipi bir derecelendirmeye sahip olan ölçekte 14 madde bulunmaktadır. Ölçeğin uygulama süresi yaklaşık 5 dakikadır. Ölçek, Varlık Teorisi ve Artımsal Teori olarak adlandırılan iki boyutlu bir yapıya sahiptir. Zekânın sabit ve değişmez 
bir özellik olduğunu yansıtan varlık teorisi boyutunda 7 madde bulunmaktadır. Örnek Madde: Belirli bir zekâ düzeyine sahipsinizdir ve bunu değiştirmek için yapacak çok şeyiniz yoktur. Zekânın bireysel çabalar ile geliştirilebilen bir özellik olduğunu yansıtan artımsal teori boyutunda 7 madde yer almaktadır. Örnek Madde: Sarf ettiğiniz çaba zekânızı geliştirir. Ölçeğin orijinal formunun psikometrik özellikleri, 940’1 (495 erkek ve 445 kız) Mısır’dan ve 162'si (65 erkek ve 97 kız) Avusturya'dan olmak üzere toplam 1102 üniversite öğrencisinden oluşan iki ayrı çalışma grubu üzerinde incelenmiştir. ÖZTÖ’nün yapı geçerliğini ortaya koymak amacıyla, AFA ve DFA uygulanmış, Misır ve Avusturya örneklemlerinden elde edilen veriler ayrı ayrı analize alınmıştır. Mısır örnekleminden elde edilen veriler üzerinden yapılan AFA sonucunda, açıklanan varyans oranının \%50.80 olduğu, varlık teorisi alt ölçeğinde yer alan maddelerin faktör yüklerinin .44 ile .86 arasında değiştiği, artımsal teori alt ölçeğinde yer alan maddelerin faktör yüklerinin ise .51 ile .70 arasında sıralandığ1 belirlenmiştir. DFA sonuçları, Mısır örnekleminden elde edilen iki faktörlü yapının yeterli uyum indekslerine sahip olduğunu göstermiştir $\left[X^{2}=86.30, \mathrm{sd}=75, \mathrm{RMSEA}=.04, \mathrm{SRMR}=.04\right.$, AGFI=.96, PGFI=.35 ve CFI=.99]. Misır örnekleminden elde edilen veriler üzerinden hesaplanan iç tutarlılık katsayıları, varlık teorisi boyutu için .83 ve artımsal teori boyutu için .75 olarak bulunmuştur. Avusturya örnekleminden elde edilen veriler üzerinden uygulanan AFA sonucunda, açıklanan varyans oranının \%44.50 olduğu, varlık teorisi alt ölçeğinde yer alan maddelerin faktör yüklerinin .52 ile .86 arasında değiştiği ve artımsal teori alt ölçeğinde yer alan maddelerin faktör yüklerinin ise .56 ile .71 arasında sıralandığı saptanmıştır. DFA sonuçları, Avusturya örnekleminden elde edilen iki faktörlü yapının yeterli uyum indeksleri verdiğini ortaya koymuştur $\left[X^{2}=83.70, \mathrm{sd}=75 \mathrm{RMSEA}=.05, \mathrm{SRMR}=.05, \mathrm{AGFI}=.95 \mathrm{PGFI}=.38\right.$ ve $\mathrm{CFI}=.98]$. Avusturya örnekleminden elde edilen veriler üzerinden hesaplanan iç tutarlık katsayıları, varlık teorisi alt ölçeği için .78 ve artımsal teori alt ölçeği için .76 olarak bulunmuştur.

Başarl Yönelimleri Ölçeği (BYÖ)

BYÖ Midgley vd. (1998) tarafından geliştirilmiş, Akın ve Çetin (2007) tarafından Türkçe'ye uyarlanmıştır. Ölçek 5'li likert tipi bir derecelendirmeye sahiptir. Ölçeğin orijinal formu 6's1 öğrenme yönelimi, 6's1 performans-yaklaşma yönelimi ve 6's1 da performanskaçınma yönelimine ait olmak üzere toplam 18 maddeden oluşmaktadır. Ölçeğin öğrenme yönelimi alt boyutunda bireyin öğrenme sürecinde öğreneceği materyali veya konuyu tam anlamıyla öğrenmek istemesiyle ilişkili maddeler bulunmaktadır. Örnek Madde: Okulda yaptığım çalışmaların en önemli amacı kendimi geliştirmektir. Performans-yaklaşma yönelimi 
alt boyutunda, bireyin iyi bir öğrenci profili sergileyerek diğer bireylerden olumlu değerlendirmeler kazanmak için öğrenmek istemesini yansıtan maddeler bulunmaktadır. Örnek Madde: Sınıftaki diğer öğrencilerin başarılı birisi olduğumu düşünmesi benim için önemlidir. Performans-kaçınma yönelimi alt boyutunda ise, bireyin yeteneksiz görünmemek ve negatif değerlendirmelerden kaçınmak için öğrenmek istemesini yansıtan maddeler bulunmaktadır. Örnek Madde: Çalışmalarımı yapmamın nedeni, diğer öğrencilerin beceriksiz olduğumu düşünmemesini sağlamaktır. Ölçeğin Türkçe formunun yapı geçerliği DFA ile incelenmiş ve ölçekte yer alan 13. madde uyum indekslerini bozduğu için ölçekten çıkarılmıştır. Dolayısıyla 18 maddeden oluşan ve ölçekteki üç faktörün de 6 madde ile ölçüldüğü orijinal formdan farklı olarak, ölçeğin Türkçe formunda öğrenme yönelimi ve performans-yaklaşma yönelimi faktörleri 6 , performans kaçınma yönelimi faktörü ise 5 madde ile ölçülmektedir. Ölçeğin orijinal formunun güvenirliği iç tutarlılık (Cronbach Alpha) güvenirlik katsayısı ile hesaplanmıştır. Hesaplanan iç tutarlık katsayıları, öğrenme yönelimi eğilimi alt ölçeği için .83, performans-yaklaşma yönelimi alt ölçeği için .86 ve performanskaçınma yönelimi alt ölçeği için .74 olarak bulunmuştur. BYÖ’nün Türkçe formunun güvenirliği hesaplanırken iç tutarlılık katsayısının yanı sıra test tekrar test güvenirlik katsayısı da incelenmiştir. İç tutarlılık güvenirlik katsayıları, öğrenme yönelimi alt ölçeği için .77, performans yaklaşma yönelimi alt ölçeği için .79 ve performans kaçınma yönelimi alt ölçeği için .78 olarak belirlenmiştir. Ölçeğin test-tekrar test güvenirliği ise her bir alt ölçek için sırasıyla $.95, .91$ ve .94 olarak hesaplanmıştır. Başarı yönelimleri ölçeği için bu çalışmada hesaplanan iç tutarlılık katsayıları; öğrenme yönelimi alt ölçeği için .67, performans-yaklaşma yönelimi alt ölçeği için .74 ve performans-kaçınma yönelimi alt ölçeği için .78 şeklindedir. Genel olarak güvenirlik katsayısı .70 ve üzerinde olan ölçeklerin güvenir olduğu kabul edilmektedir (Domino \& Domino, 2006; Fraenkel, Wallend \& Hyun, 2012; Nunnaly \& Bernstein, 1994; Pallant, 2005; Tezbaşaran, 1997). Performans-yaklaşma ve performanskaçınma yönelimi alt ölçekleri için hesaplanan güvenirlik katsayıları bu şartı sağlar niteliktedir. Madde sayısı az olan (10 veya daha az) ölçekler için ise güvenirlik katsayısının .60 'ın üzerinde olması ölçeğin güvenirliği için yeterli görülmektedir (Sipahi, Yurtkoru ve Çinko, 2010, Şeker ve Gençdoğan, 2006). Buna göre, öğrenme yönelimi alt ölçeği için hesaplanan güvenirlik katsayının da kabul edilebilir sınırlar içerisinde yer aldığı söylenebilir. Işlem

ÖZTÖ’nün Türkçe’ye uyarlanması sürecinde öncelikle Greg Yates ile elektronik posta yoluyla iletişime geçilmiş ve ölçeğin uyarlanabileceğine ilişkin gerekli izin alınmıştır. Gerekli izin alındıktan sonra ölçeğin kaynak dil olan İngilizce'den hedef dil olan Türkçe'ye çeviri 
sürecine geçilmiştir. Ölçeğin kaynak dilden hedef dile çeviri sürecinde, yargılayıcı tek çeviri yöntemi, yargılayııı geri çeviri yöntemi, istatistiksel analizlere dayalı tek çeviri yöntemi ve istatistiksel analizlere dayalı geri çeviri yöntemi olmak üzere dört farklı yöntem kullanılabilmektedir (Hambleton \& Bollwark, 1991). Yargılayıcı tek çeviri yönteminde, ölçek bir ya da birkaç çevirmen tarafından kaynak dilden hedef dile çevrilir. Daha sonra başka bir grup orijinal form ile çeviri formu karşılaştırarak iki formun dilsel açıdan birbirine denk olup olmadığı hakkında karar verir. Bu aşamada karar vericiler gerekli gördükleri takdirde çeviri formda değişiklik yapabilirler (Hambleton \& Kanjee, 1993). Yargılayıcı geri çeviri yönteminde ise, ilk olarak ölçek bir çevirmen grubu tarafından kaynak dilden hedef dile çevrilir. İkinci aşamada, farklı çevirmenlerden oluşan ikinci bir çeviri grubu yapılan çeviriyi tekrar kaynak dile çevirir. Son aşamada ise ölçeğin orijinal formu ile geri çeviri yöntemi ile elde edilen form karşılaştırılarak iki formun dilsel açıdan eş değer olup olmadığı konusunda karar verilir (Maneesriwongul \& Dixon, 2004). Hem yargılayıcı tek çeviri yöntemi hem de yargılayıcı geri çeviri yöntemi, bir bireyin ya da grubun orijinal ve çeviri formda yer alan maddelerin dilsel açıdan eşdeğer olup olmadığı konusundaki kararına dayanmaktadır. Dolayısıyla, dilsel eşdeğerliğin yalnızca yargılayıcı yöntemler ile incelenmesi, orijinal form ile çeviri formun denk olup olmadığı konusunda verilen kararın öznel olmasına neden olabilmektedir. $\mathrm{Bu}$ durum çeviri sürecinde yargılayıcı yöntemlerle birlikte istatistiksel analizlere dayalı yöntemlerden de yararlanılmasını gerekli kılmaktadır. İstatistiksel analizlere dayalı yöntemlerde, orijinal ve çeviri formdan alınan puanlar arasındaki korelasyon hesaplanmakta ya da bu puanlar arasındaki farkın anlamlılı̆̆ı ilişkili örneklem t testi ile incelenmektedir (Hambleton \& Bollwark, 1991). Bir ölçme aracının geliştirildiği kültürden farklı bir kültüre uyarlanması sürecindeki en kritik işlemi, ölçeğin kaynak dilden hedef dile çeviri çalışmasının oluşturduğu (Beaton, Bombardier, Guillemin \& Ferraz, 2000; Geisinger, 1994; Hofstede, 2001) dikkate alındığında, çeviri sürecinde hem yargılayııı hem de istatistiksel analizlere dayalı yöntemlerden yararlanılması önem arz etmektedir. ÖZTÖ’nün Türkçe'ye çeviri sürecinde ilk olarak yargılayıcı tek çeviri yönetiminden yararlanılmıştır. Ölçek 2 İngiliz dil bilimci ve iyi düzeyde İngilizce bilen 3 eğitim bilimi uzmanı olmak üzere toplam 5 kişi tarafindan Türkçe'ye çevrilmiştir. Bu çeviriler karşılaştırılarak her bir madde için, o maddeyi en iyi temsil ettiği düşünülen Türkçe ifadeler belirlenmiştir. Ardından Türkçe ve İngilizce formlar karşılaştırılmış ve eğitim bilimleri alanından iki öğretim üyesi tarafından tekrar incelenerek yapılan çevirilerdeki tartışmalı maddeler ele alınmıştır. Böylelikle üzerinde uzlaşılan nihai bir form elde edilmiştir. Elde edilen Türkçe form ile İngilizce form arasındaki 
tutarlığı belirlemek için ÖZTÖ’nün Türkçe formu ile orijinal formundan alınan puanlar arasındaki korelasyon hesaplanmıştır. Bu çalışmalar dilsel eşdeğerlik için yeterli kabul edilmiştir. ÖZTÖ’nün geçerlik çalışması kapsamında yapı ve uyum geçerlikleri incelenmiştir. Yapı geçerliği için AFA ve DFA çalışmalarına yer verilmiştir. Uyum geçerliği kapsamında ÖZTÖ ile BYÖ arasındaki korelasyon hesaplanmıştır. ÖZTÖ’nün güvenirliği iç tutarlılık, test yarılama ve test tekrar test yöntemleriyle incelenmiştir. ÖZTÖ’nün madde ayırt ediciliği kapsamında ise düzeltilmiş madde toplam korelasyonu ve \%27'lik alt-üst grup karşılaştırmalarına yer verilmiştir. Ölçeğin geçerlik ve güvenirlik analizleri SPSS 20.0 ve AMOS 20.0 paket programları kullanılarak gerçekleştirilmiştir. ÖZTÖ’nün Türkçe’ye uyarlanması sürecinde izlenen adımlar Tablo 1'de özetlenmiştir.

Tablo 1 ÖZTÖ’nün Türkçe’ye Uyarlanması Süreci

\begin{tabular}{|c|c|}
\hline İznin Alınması & $\begin{array}{l}\text {-Greg Yates ile elektronik posta yoluyla iletişime geçilip ölçeğin } \\
\text { uyarlanabileceğine ilişkin gerekli iznin alınması }\end{array}$ \\
\hline $\begin{array}{l}\text { Ölçeğin Türkçe } \\
\text { Formunun Oluşturulması }\end{array}$ & $\begin{array}{l}\text {-Ölçeğin } 2 \text { İngiliz dil bilimci ve iyi düzeyde İngilizce bilen } 3 \text { eğitim } \\
\text { bilimi uzmanı olmak üzere toplam } 5 \text { kişi tarafından kaynak dil olan } \\
\text { İngilizce'den hedef dil olan Türkçe'ye çevrilmesi } \\
\text {-Her bir madde için o maddeyi en iyi temsil ettiği düşünülen Türkçe } \\
\text { ifadelerin belirlenmesi } \\
\text {-Elde edilen Türkçe form ile İngilizce form arasındaki tutarlığın } \\
\text { belirlenmesi ççin dilsel eşdeğerlik çalışmasının yapılması }\end{array}$ \\
\hline Geçerlik Çalışmaları & $\begin{array}{l}\text {-Yapı Geçerliği: AFA ve DFA'nı̈n uygulanması } \\
\text {-Uyum Geçerliği: ÖZTÖ ile BYÖ arasındaki korelasyonun hesaplanması }\end{array}$ \\
\hline Güvenirlik Çalışması & $\begin{array}{l}\text {-İç tutarlık (Cronbach Alpha), Test Yarılama (Split Half) ve Test Tekrar } \\
\text { Test güvenirlik katsayılarının hesaplanması }\end{array}$ \\
\hline Madde Analizi & $\begin{array}{l}\text {-Düzeltilmiş madde toplam korelasyonunun hesaplanması ve \%27'lik } \\
\text { alt-üst grup karşılaștırmalarına yer verilmesi }\end{array}$ \\
\hline
\end{tabular}

\section{Bulgular}

\section{Dilsel Eşdeğerlik}

ÖZTÖ’nün dilsel eşdeğerlik çalışmasından elde edilen bulgular, Türkçe ve orijinal formda yer alan maddeler arasındaki korelasyonların .81 ile .96 arasında değiştiğini göstermiştir. Türkçe ve orijinal formlardan elde edilen puanlar arasındaki korelasyon, Varlık Teorisi alt ölçeğin için .95 ve Artımsal Teori alt ölçeği için .92 olarak bulunmuştur. Bulgulara dayanarak, ölçeğin Türkçe formu ile İngilizce formunun dilsel açıdan eşdeğer olduğu söylenebilir. ÖZTÖ’nün Türkçe ve İngilizce formlarında yer alan maddelerin korelasyonlarına ilişkin bulgular Tablo 2'de gösterilmiştir. 
Tablo 1 ÖZTÖ Maddelere Göre Dilsel Eşdeğerlik Bulguları

\begin{tabular}{cccc}
\hline Madde No & r & Madde No & r \\
\hline ÖZTÖ 1 & .94 & ÖZTÖ 8 & .94 \\
ÖZTÖ 2 & .86 & ÖZTÖ 9 & .88 \\
ÖZTÖ 3 & .81 & ÖZTÖ 10 & .93 \\
ÖZTÖ 4 & .89 & ÖZTÖ 11 & .84 \\
ÖZTÖ 5 & .90 & ÖZTÖ 12 & .93 \\
ÖZTÖ 6 & .82 & ÖZTÖ 13 & .95 \\
ÖZTÖ 7 & .92 & ÖZTÖ 14 & .96 \\
\hline
\end{tabular}

\section{Yapı Geçerliği}

Bu çalışmada ÖZTÖ’nün yapı geçerliğini incelemek amacıyla AFA ve DFA uygulanmıştır. Açımlayıcı Faktör Analizi (AFA)

AFA gerçekleştirilmeden önce veri setinin faktör analizi için uygun olup olmadığının belirlenmesi gerekir. Örneklem büyüklüğü bu incelemede ilk sırada yer almaktadır. Faktör analizi çalışmalarında yer alması gereken katılımcı sayısı konusunda farklı araştırmacılar değişik öneriler getirmiştir. Cattell (1978) faktör analizi çalışmalarında ölçekteki madde sayısının 3 ile 6 katı kadar katılımcının çalışma grubuna dâhil edilmesini önermekte ve faktör analizi için 200 katılımcıyı kabul edilebilir, 500 katılımcıyı ise oldukça iyi bir sayı olarak ifade etmektedir. Hair, Anderson, Tatham ve Grablowsky (1979) faktör analizi için, ölçekte yer alan madde sayısının 20 katı kadar katılımcının çalışma grubuna dâhil edilmesini önermektedir. Gorsuch (1983) faktör analizi çalışmalarında ölçekte yer alan her madde için çalışma grubunda en az 5 katılımcının bulunması önermekte, bununla birlikte katılımcı sayısının 100'den az olmaması gerektiğini belirtmektedir (Cramer, 2003). Crowley ve Lee (1992) faktör analizi için 100 katılımcıyı yetersiz, 200'ü ortalama, 300’ü iyi, 500’ü çok iyi ve 1000 katılımciyı mükemmel olarak nitelendirmektedir (Akbulut, 2010). Ferguson ve Cox (1993) faktör analizi çalışmalarında ölçüt olarak alınması gereken katılımcı sayısının en az 100 olduğunu belirtmektedir. Kline (1994), faktör analizinde güvenilir sonuçlar elde etmek için 200 kişilik örneklemin genellikle yeterli olacağını, faktör yapısının açık ve az sayıda olduğu durumlarda bu rakamın 100'e kadar indirilebileceğini, ancak büyük örneklemlerle çalışmanın daha uygun olacağını vurgulamaktadır. Bryman ve Cramer (2001) ise, faktör analizi çalışmalarında araştırmaya dâhil edilmesi gereken katılımcı sayısı belirlenirken, ölçekteki madde sayısının beş ya da on ile çarpılmasıyla elde edilen değerin ölçüt olarak alınması gerektiğini ifade etmektedir. Faktör analizi için uygun örneklem büyüklüğü tahmininde farklı yaklaşımlar dikkate alındığında, literatürde yer verilen ölçütlerden en az ikisini karşılayacak bir büyüklüğe ulaşılması önerilmektedir (Çokluk, Şekercioğlu ve 
Büyüköztürk, 2012). Bu ölçütlere göre, araştırmadaki katılımcı sayısının faktör analizi için yeterli olduğu söylenebilir.

Örneklemin veri analizine uygun olup olmadığını belirlemek için yapılacak bir diğer işlem Kaiser-Meyer-Oklin'in (KMO) ve Barlett Sphericity testlerinin gerçekleştirilmesidir. KMO 0 ile 1 arasında değişen değerler alabilmektedir. Kaiser'e göre (1974) 0.5'in üzerindeki KMO değerleri kabul edilebilir değerledir (Field, 2009). Bununla birlikte, 0.5 ile 0.7 arasındaki KMO değerlerinin orta, 0.7 ile 0.8 arasındaki değerlerin iyi, 0.8 ile 0.9 arasındaki değerlerin çok iyi ve 0.9 'un üzerindeki değerlerin ise mükemmel olduğu kabul edilmektedir (Hutcheson \& Sofroniou, 1999). Bu çalışmada KMO örneklem uygunluk katsayıs1 .825, Barlett Sphericity testi değeri ise $1253.10(\mathrm{p}<.001$, df=91) bulunmuştur. Bu sonuca göre, verilerin faktör analizine uygun olduğu söylenebilir. $\mathrm{Bu}$ tespitin ardından gerçekleştirilen AFA'da temel bileşenler yöntemi (principal components) ve oblik döndürme sonucunda toplam varyansın \%42.31'ini açıklayan ve orijinal formdaki maddelerle bire bir örtüşen 2 faktörlü bir yapı elde edilmiştir. Bu döndürme tekniğinin kullanılması faktörlerin birbiri ile ilişkili olmasından kaynaklanmaktadır. Belirlenen faktörler ölçeğin orijinal formunda olduğu gibi "Varlık Teorisi" ve "Artımsal Teori” olarak isimlendirilmiştir. AFA sonucunda ortaya çıkan, Varlık Teorisi alt ölçeği 7 maddeden oluşmakta ve toplam varyansın \%25.04'ünü açıklamaktadır. Varlık teorisi alt ölçeğinde yer alan maddelerin faktör yükleri .61 ile .76 arasında değişmektedir. Artımsal teorisi alt ölçeği 7 maddeden oluşmakta ve toplam varyansın \%17.27'sini açıklamaktadır. Artımsal Teori alt ölçeğinde yer alan maddelerin faktör yükleri .50 ile .67 arasında sıralanmaktadır. Ölçekte bulunan tüm maddelerin faktör yükleri .30 alt sınırının (Büyüköztürk, 2010) üstünde olduğu için ölçekten herhangi bir maddenin çıkarılmasına gerek duyulmamıştır. Ölçeğin faktör yükleri ve açıkladıkları varyans oranlarına ilişkin bilgiler Tablo 3'de sunulmuştur.

Tablo 3 ÖZTÖ’nün Faktör Yapısı ve Faktör Yükleri

\begin{tabular}{cclcc}
\hline \multirow{2}{*}{ Faktör } & Madde No & \multicolumn{1}{c}{ MADDELER } & $\begin{array}{c}\text { Faktör } \\
\text { Yükü }\end{array}$ \\
\hline & ÖZTÖ 1 & $\begin{array}{l}\text { Belirli bir zekâ düzeyine sahipsinizdir ve bunu değiştirmek için } \\
\text { yapacak çok şeyiniz yoktur. }\end{array}$ & .74 \\
\cline { 2 - 5 } & ÖZTÖ 2 & Zorluklar ve güçlükler, sizi zekânızı geliştirmekten alıkoyar. & .64 \\
\cline { 2 - 5 } & ÖZTÖ 4 & Bir görevde başarısız olursanız zekânızı sorgularsınız. & .76 \\
\cline { 2 - 5 } Varlık & ÖZTÖ 7 & Bir görevde iyi performans göstermek, başkalarına zeki olduğunuzu & .62 \\
& gösterme yoludur. & Çok çaba sarf ettiğinizde zeki olmadığınızı göstermiş olursunuz. & .61 \\
\cline { 2 - 5 } & ÖZTÖ 8 & Yeteneklerinizi, ne kadar zeki olduğunuz belirler. & .73 \\
\cline { 2 - 5 } & ÖZTÖ 14 & Sabit bir zeka düzeyiyle doğarsınız. & .70 \\
\cline { 2 - 5 } & & Açıkladığı Varyans \% & $\mathbf{2 5 . 0 4}$ \\
\hline
\end{tabular}




\begin{tabular}{|c|c|c|c|}
\hline \multirow{7}{*}{$\begin{array}{l}\text { Artımsal } \\
\text { Teori }\end{array}$} & ÖZTÖ 3 & Sarf ettiğiniz çaba zekânızı geliştirir. & .67 \\
\hline & ÖZTÖ 5 & Başkalarından gelen eleştiriler zekânızın gelişmesine yardımcı olabilir. & .55 \\
\hline & ÖZTÖ 6 & Gerçekten çaba gösterirseniz zekânızı geliştirebilirsiniz. & .63 \\
\hline & ÖZTÖ 9 & Yeni şeyler öğrendiğinizde temel zekâ düzeyiniz gelişir. & .62 \\
\hline & ÖZTÖ 10 & $\begin{array}{l}\text { Bir görevde başarısız olsanız bile zekânıza güvenmeye devam } \\
\text { edersiniz. }\end{array}$ & .50 \\
\hline & ÖZTÖ 11 & $\begin{array}{l}\text { Bir görevi başarılı bir şekilde yerine getirmek, zekânızın gelişmesine } \\
\text { yardımcı olabilir }\end{array}$ & .61 \\
\hline & ÖZTÖ 13 & $\begin{array}{l}\text { Bir görevi yerine getirmeden önce iyi bir hazırlık yapmak, zekânızı } \\
\text { geliştirme yoludur. }\end{array}$ & 67 \\
\hline & & Açıkladığı Varyans \% & 17.27 \\
\hline & & AÇIKLANAN TOPLAM VARYANS \% & 42.31 \\
\hline
\end{tabular}

\section{Doğrulayıcı Faktör Analizi (DFA)}

$\mathrm{Bu}$ araştırmada, ÖZTÖ’nün orijinal formunun faktör yapısının Türk örneklemde doğrulanıp doğrulanmayacağını ortaya koymak üzere DFA uygulanmıştır. DFA'da sınanan modelin yeterliliğini ortaya koymak üzere pek çok uyum indeksi kullanılmaktadır. Bu çalışmada yapılan DFA için Ki-Kare Uyum Testi (Chi-Square Goodness), iyilik uyum indeksi (Goodness of Fit Index, GFI), düzeltilmiş iyilik uyum indeksi (Adjustment Goodness of Fit Index, AGFI) karşılaştırmalı uyum indeksi (Comparative Fit Index, CFI), tucker lewis indeksi (TLI), fazlalık uyum indeksi (Incremental Fit Index, IFI), tahmin hatalarının ortalamasının karekökü (Root Mean Square Error of Approximation, RMSEA) ve standartlaştırılmış hata kareleri ortalamasının karekökü (Standardized Root Mean Square Residual, SRMR) uyum indeksleri incelenmiştir. GFI, CFI ve IFI indeksleri için .90 değeri kabul edilebilir uyuma ve .95 değeri mükemmel uyuma işaret etmektedir. (Bentler, 1980; Bentler \& Bonett, 1980; Marsh, Hau, Artelt, Baumert \& Peschar, 2006). Aynı şekilde, TLI için .90 değeri kabul edilebilir uyum ve .95 değeri mükemmel uyum ölçütü olarak alınmaktadır (Meydan \& Şeşen, 2011). AGFI için .85 değeri kabul edilebilir uyumu ve .90 değeri mükemmel uyumu ifade etmektedir (Schermelleh-Engel \& Moosbrugger, 2003). RMSEA için .08 kabul edilebilir uyum ve .05 mükemmel uyum ölçütü olarak alınmaktadır (Brown \& Cudeck, 1993; Byrne \& Campbell, 1999). SRMR için ise .05 değeri mükemmel uyuma ve .10 değeri kabul edilebilir uyuma işaret etmektedir ( $\mathrm{Hu} \&$ Bentler, 1999). Yapılan DFA'da elde edilen modelin uyum indeksleri incelenmiş ve minimum ki-kare değerinin $\left(\chi^{2}=144.213, \mathrm{~N}=415, \mathrm{p}=.00\right)$ anlamlı olduğu görülmüştür. Uyum indeksi değerleri ise GFI=.95, AGFI=.93, CFI=.97, TLI=.93, $\mathrm{IFI}=.94, \mathrm{RMSEA}=.047$ ve $\mathrm{SRMR}=.043$ olarak bulunmuştur. Sınanan modelin yeterliğini ortaya koymak amaciyla incelenen uyum indekslerine ilişkin kabul edilebilir ve mükemmel uyum değerleri ile DFA'dan elde edilen uyum indeksi değerleri ve bu doğrultuda ortaya çıkan sonuçlar Tablo 4'de gösterilmiştir. 
Tablo 4 Araştırmada İncelenen Uyum İndekslerine İlişkin Mükemmel ve Kabul edilebilir Uyum Değerleri ile DFA'dan Elde Edilen Uyum İndeksi Değerleri

\begin{tabular}{lllcc}
\hline $\begin{array}{c}\text { Uyum } \\
\text { Indeksleri }\end{array}$ & \multicolumn{1}{c}{$\begin{array}{c}\text { Mükemmel } \\
\text { Uyum Ölçütü }\end{array}$} & $\begin{array}{c}\text { Kabul Edilebilir } \\
\text { Uyum Ölçütü }\end{array}$ & $\begin{array}{c}\text { DFA'dan Elde Edilen } \\
\text { Uyum İndeksleri }\end{array}$ & Sonuç \\
\hline$X^{2} / \mathrm{sd}$ & $0 \leq X^{2} / \mathrm{sd} \leq 2$ & $2 \leq X^{2} / \mathrm{sd} \leq 3$ & 1.90 & Mükemmel Uyum \\
GFI & $.95 \leq \mathrm{GFI} \leq 1.00$ & $.90 \leq \mathrm{GFI} \leq 95$ & .95 & Mükemmel Uyum \\
AGFI & $.90 \leq \mathrm{AGFI} \leq 1.00$ & $.85 \leq \mathrm{AGFI} \leq .90$ & .93 & Mükemmel Uyum \\
CFI & $.95 \leq \mathrm{CFI} \leq 1.00$ & $.90 \leq \mathrm{CFI} \leq .95$ & .97 & Mükemmel Uyum \\
TLI & $.95 \leq \mathrm{TLI} \leq 1.00$ & $.90 \leq \mathrm{TLI} \leq .95$ & .93 & Kabul Edilebilir Uyum \\
IFI & $.95 \leq \mathrm{IFI} \leq 1.00$ & $.90 \leq \mathrm{IFI} \leq .95$ & .94 & Kabul Edilebilir Uyum \\
RMSEA & $.00 \leq \mathrm{RMSEA} \leq .05$ & $.05 \leq \mathrm{RMSEA} \leq .08$ & .047 & Mükemmel Uyum \\
SRMR & $.00 \leq \mathrm{SRMR} \leq .05$ & $.05 \leq \mathrm{SRMR} \leq .10$ & .043 & Mükemmel Uyum \\
\hline
\end{tabular}

Tablo 4'deki uyum indekslerine ilişkin mükemmel ve kabul edilebilir uyum ölçütleri, DFA'dan elde edilen iki faktörlü modelin uyumlu olduğunu ortaya koymaktadır. İki boyutlu modele ilişkin faktör yükleri Şekil 1'de görülmektedir. Şekil 1'de görülebileceği gibi "Varlık Teorisi” alt boyutu için faktör yükleri .52 ile .73 arasında, “Artımsal Teori” alt boyutu için .39 ile .59 arasında değişmektedir.

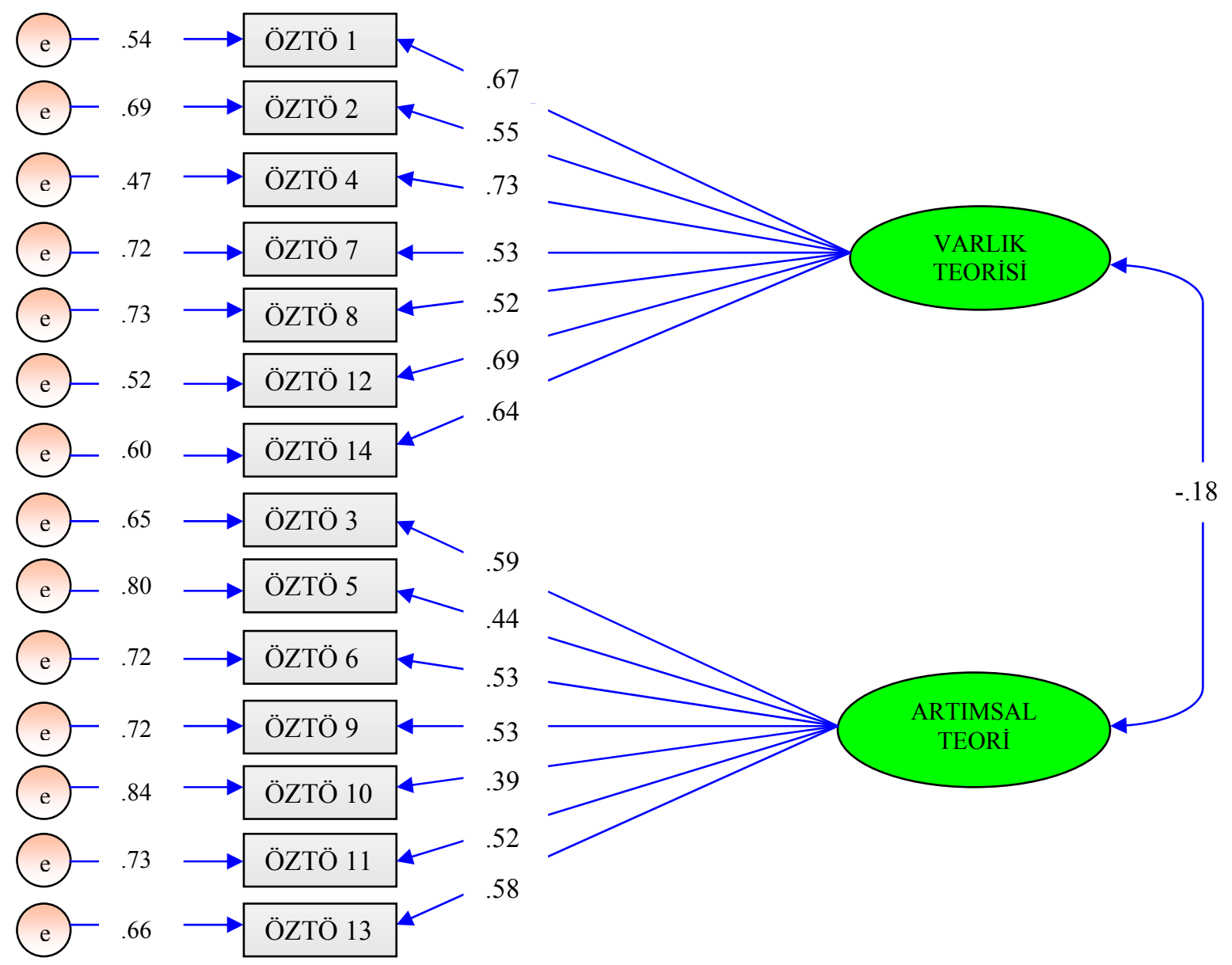

Şekil 1 ÖZTÖ’ye İlişkin Path Diyagramı, Faktör Yükleri ve Hata Varyansları 
DFA sonucu elde edilen iki faktörlü modele ilişkin faktör yükleri ile standart hata, kritik oran, hata varyansı ve $\mathrm{R}^{2}$ değerleri Tablo 5 'de sunulmuştur.

Tablo 5'de yer alan bulgular incelendiğinde, kritik oran değerlerinin Varlık Teorisi alt ölçeği için 10.31 ile 15.74 arasında, Artımsal Teori alt ölçeği için 7.07 ile 11.09 arasında değiştiği ve kritik oran değerlerinin tüm maddeler için anlamlı olduğu görülmektedir. Anlamlı olmayan kritik oran değerleri, söz konusu kritik oran değerlerine ilişkin maddelerin modelden çıkarılması gerektiğine işaret etmekte veya araştırmadaki katılımcı sayısının faktör analizi için yetersiz olduğunun göstergesi olarak değerlendirilmektedir (Byrne, 2010). Dolayısıyla, DFA sonucunda elde edilen kritik oran değerleri, araştırmadaki katılımcı sayısının faktör analizi için yeterli olduğunu doğrulamakta ve modelden çıkarılması gereken madde bulunmadığını ortaya koymaktadır.

Tablo 5 ÖZTÖ’ye İlişkin Faktör Yükleri ile Standart Hata, Kritik Oran, Hata Varyansı ve R ${ }^{2}$ Değerleri

\begin{tabular}{ccccccc}
\hline Faktörler & Maddeler & $\begin{array}{c}\text { Faktör } \\
\text { Yükleri }\end{array}$ & $\begin{array}{c}\text { Standart } \\
\text { Hata }\end{array}$ & $\begin{array}{c}\text { Kritik } \\
\text { Oran }\end{array}$ & $\begin{array}{c}\text { Hata } \\
\text { Varyansı }\end{array}$ & $\mathbf{R}^{2}$ \\
\hline & ÖZTÖ 1 & .67 & .058 & $14.228^{*}$ & .54 & .46 \\
& ÖZTÖ 2 & .55 & .059 & $11.186^{*}$ & .69 & .31 \\
Varlık & ÖZTÖ 4 & .73 & .056 & $15.740^{*}$ & .47 & .53 \\
Teorisi & ÖZTÖ 7 & .53 & .058 & $10.513^{*}$ & .72 & .28 \\
& ÖZTÖ 8 & .52 & .060 & $10.308^{*}$ & .73 & .27 \\
& ÖZTÖ 12 & .69 & .055 & $14.652^{*}$ & .52 & .48 \\
& ÖZTÖ 14 & .64 & .057 & $13.180^{*}$ & .60 & .40 \\
\hline Artımsal & ÖZTÖ 3 & .59 & .027 & $11.092^{*}$ & .65 & .35 \\
Teori & ÖZTÖ 5 & .44 & .027 & $8.031^{*}$ & .80 & .20 \\
& ÖZTÖ 6 & .53 & .023 & $9.814^{*}$ & .72 & .28 \\
& ÖZTÖ 9 & .53 & .027 & $9.794^{*}$ & .72 & .28 \\
& ÖZTÖ 10 & .39 & .027 & $7.073^{*}$ & .84 & .16 \\
& ÖZTÖ 11 & .52 & .021 & $9.619^{*}$ & .73 & .27 \\
& ÖZTÖ 13 & .58 & .019 & $10.940^{*}$ & .66 & .34 \\
\hline
\end{tabular}

$\overline{\mathrm{p}<.001}$

\section{Uyum Geçerliği}

Örtük zekâ teorisine ilişkin alanyazın incelendiğinde, zekâ hakkında sahip oldukları inançların bireylerin başarı yönelimleri üzerinde anlamlı bir etkiye sahip olduğu görülmektedir (Bempechat, London \& Dweck, 1991; Cury, Elliot, Da Fonseca \& Moller, 2006; Dupeyrat \& Mariné, 2005; Dweck \& Master, 2008; Dweck \& Molden, 2005; Hong, Chiu, Dweck \& Lin, 1998; Knee, 1998; Knee, Nanayakkara, Vietor, Neighbors \& Patrick, 2001; Robins \& Pals, 2002). Varlık teorisini benimseyip zekânın sabit ve değiştirilmez bir özellik olduğunu inanan öğrenciler, performans-kaçınma ya da performans-yaklaşma yönelimlidirler. Artımsal teoriyi benimseyip zekânın bireysel çabalar ile arttırılabileceğine 
inanan öğrenciler ise öğrenme yönelimlidirler (Dweck, 1999; Dweck \& Leggett, 1988; Vandewalle 1997). Bu noktadan hareketle, ÖZTÖ’nün uyum geçerliği incelenirken, ÖZTÖ ile BYÖ arasında korelasyon hesaplanmıştır. Bu kapsamda, zekâya ilişkin varlık teorisinin performans-kaçınma ve performans-yaklaşma yönelimi ile pozitif; öğrenme yönelimi ile negatif bir ilişki içerisinde olduğu varsayımı sınanmıştır. Zekâya ilişkin artımsal teorinin ise öğrenme yönelimi ile pozitif; performans kaçınma ve performans yaklaşma yönelimi ile negatif bir ilişki içerisinde olduğu hipotezi test edilmiştir. Uyum geçerliği çalışmasından elde edilen bulgular Tablo 6'da gösterilmiştir.

Tablo 6 ÖZTÖ ve BYÖ Arasındaki Korelasyonlar

\begin{tabular}{|c|c|c|c|}
\hline & & \multicolumn{2}{|c|}{ ÖZTÖ } \\
\hline & & Varlık Teorisi & Artımsal Teori \\
\hline \multirow{3}{*}{ BYÖ } & Öğrenme Yönelimi & -.12 & $.69^{* *}$ \\
\hline & Performans Kaçınma Yönelimi & $.46^{* *}$ & $-.27^{* *}$ \\
\hline & Performans Yaklaşma Yönelimi & $.61^{* *}$ & -.09 \\
\hline
\end{tabular}

Uyum geçerliği çalışmasından elde edilen bulgulara göre, varlık teorisi ile performans kaçınma $[\mathrm{r}=.46, \mathrm{p}<.01]$ ve performans yaklaşma yönelimi $[\mathrm{r}=.61, \mathrm{p}<.01]$ arasında pozitif anlamlı bir ilişki bulunmaktadır. Varlık teorisi ile öğrenme yönelimi arasında ise istatistiksel olarak anlamlı olmayan negatif bir ilişki tespit edilmiştir [r=-.12, $\mathrm{p}>.05]$. Artımsal teori ile başarı yönelimleri arasındaki ilişkiler incelendiğinde, artımsal teorinin öğrenme yönelimi ile pozitif anlamlı $[\mathrm{r}=.69, \mathrm{p}<.01]$ ilişki içerisinde olduğu görülmektedir. Artımsal teori ile performans kaçınma yönelimi arasında negatif yönde ve istatistiksel olarak anlamlı ancak zayıf bir ilişki [r=-.27, $\mathrm{p}<.01]$ saptanmıştır. Artımsal teori ile performans yaklaşma yönelimi arasında ise istatistiksel açıdan anlamlı olmayan negatif bir ilişki belirlenmiştir [r=-.09, $\mathrm{p}>.05]$. Zekâya ilişkin varlık teorisini benimseyen öğrencilerin daha çok performans yöneliminde, artımsal teoriyi benimseyen öğrencilerin ise daha çok öğrenme yöneliminde, oldukları (Braten \& Strømsø, 2004; Dweck, 1991) göz önünde alındığında, ÖZTÖ ile BYÖ arasındaki korelasyonlar, ÖZTÖ’nün uyum geçerliğinin sağlandığına yönelik bir kanıt olarak değerlendirilebilir.

\section{Güvenirlik}

ÖZTÖ’nün güvenirliği iç tutarlılık (Cronbach Alpha), test yarılama (split half) ve test tekrar test yöntemleriyle hesaplanmıştır. 415 öğrenciden elde edilen iç tutarlılık güvenirlik katsayısı varlık teorisi alt ölçeği için .81 ve artımsal teori alt ölçeği için .71 olarak hesaplanmıştır. Test yarılama yöntemiyle hesaplanan güvenirlik katsayıları varlık teorisi alt ölçeği için .83 ve artımsal teori alt ölçeği için .71 şeklindedir. ÖZTÖ’nün test tekrar test güvenirliğini saptamak için ölçek sınıf öğretmenliği bölümünde okuyan 71 öğrenciye iki hafta 
ara ile iki kez uygulanmış ve iki uygulama arasındaki korelasyonlar hesaplanmıştır. Test tekrar test yöntemi ile hesaplanan güvenirlik katsayısı varlık teorisi alt ölçeği için .95, artımsal teori alt ölçeği için .90 olarak bulunmuştur. Güvenirlik katsayıları .70 ve üzerinde olan ölçeklerin güvenilir kabul edildiği (Anastasi, 1982; Domino \& Domino, 2006; Fraenkel, Wallend \& Hyun, 2012; Leech, Barlett \& Morgan, 2005; Nunnaly \& Bernstein, 1994; Pallant, 2005; Tezbaşaran, 1997) göz önüne alındığında, Varlık Teorisi ve Artımsal Teori alt ölçekleri için hesaplanan güvenirlik katsayılarının yeterli olduğu söylenebilir. Güvenirlik çalışmalarına yönelik sonuçlar Tablo 7'de verilmiştir.

Tablo 7 ÖZTÖ’nün İç Tutarlılık, Test Yarılama ve Test Tekrar Test Yöntemleriyle Hesaplanan Güvenirlik Katsayıları

\begin{tabular}{lccc}
\hline Alt Ölçekler & $\begin{array}{c}\text { İç Tutarlılık } \\
\text { (Cronbach Alpha) }\end{array}$ & $\begin{array}{c}\text { Test Yarılama } \\
\text { (Split Half) }\end{array}$ & $\begin{array}{c}\text { Test } \\
\text { Tekrar Test }\end{array}$ \\
\hline Varlık Teorisi & .81 & .83 & .95 \\
Artımsal Teori & .71 & .71 & .90 \\
\hline
\end{tabular}

\section{Madde Analizi}

ÖZTÖ’de yer alan maddelerin toplam puanı yordama gücünü belirlemek ve ayırt edicilik düzeylerini saptamak amacıyla madde analizi yapılmıştır. Bu kapsamda düzeltilmiş madde toplam korelasyonu hesaplanmış ve \%27'lik alt-üst grup karşılaştırmalarına yer verilmiştir. Madde analize ilişkin bulgular Tablo 8'de sunulmuştur.

Tablo 8 ÖZTÖ için Madde Analizi Sonuçları

\begin{tabular}{|c|c|c|c|c|c|}
\hline Alt Ölçek & $\begin{array}{l}\text { Madde } \\
\text { No }\end{array}$ & $\begin{array}{l}\text { Madde Çıkarıldığında } \\
\text { Ölçek Alfası }\end{array}$ & $\begin{array}{l}\text { Düzeltilmiş Madde } \\
\text { Toplam Korelasyonu }\end{array}$ & $\mathbf{t}$ & \\
\hline & ÖZTÖ 1 & .778 & .605 & $25.20^{*}$ & \multirow{7}{*}{$\begin{array}{l}\mathrm{sd}=202 \\
{ }^{*} \mathrm{p}<.001\end{array}$} \\
\hline Varlık & ÖZTÖ 2 & .797 & .499 & $19.70^{*}$ & \\
\hline Teorisi & ÖZTÖ 4 & .774 & .628 & $25.95^{*}$ & \\
\hline $\mathrm{N}=415$ & ÖZTÖ 7 & .799 & .483 & $17.16^{*}$ & \\
\hline \multirow{3}{*}{$\begin{array}{c}\text { Cronbach } \\
\text { Alpha }=.81\end{array}$} & ÖZTÖ 8 & .802 & .471 & $15.96^{*}$ & \\
\hline & ÖZTÖ 12 & .782 & .588 & $24.25^{*}$ & \\
\hline & ÖZTÖ 14 & .784 & .574 & $24.03^{*}$ & \\
\hline & ÖZTÖ 3 & .658 & .471 & $14.22^{*}$ & \multirow{7}{*}{$\begin{array}{l}\mathrm{sd}=178 \\
* \mathrm{p}<.001\end{array}$} \\
\hline Artımsal & ÖZTÖ 5 & .681 & .390 & $11.23^{*}$ & \\
\hline Teori & ÖZTÖ 6 & .668 & .439 & $8.71^{*}$ & \\
\hline $\mathrm{N}=415$ & ÖZTÖ 9 & .672 & .423 & $12.00^{*}$ & \\
\hline \multirow{3}{*}{$\begin{array}{l}\text { Cronbach } \\
\text { Alpha }=.71\end{array}$} & ÖZTÖ 10 & .695 & .334 & $10.28^{*}$ & \\
\hline & ÖZTÖ 11 & .675 & .415 & $8.69^{*}$ & \\
\hline & ÖZTÖ 13 & .664 & .481 & $9.89^{*}$ & \\
\hline
\end{tabular}


Tablo 8'de görüldüğü gibi, \%27'lik alt ve üst grupların madde puanlarındaki farklara ilişkin t değerlerleri, Varlık Teorisi alt ölçeği için 15.96 ile 25.95 arasında $(s d=202, p<.001)$, Artımsal Teori alt ölçeği için 8.69 ile 14.22 arasında $(\mathrm{sd}=178, \mathrm{p}<.001)$ değişmektedir. Tablo 8'e göre ayrıca, madde toplam korelasyonunu ilişkin sonuçlar; Varlık Teorisi alt ölçeği için .47 ile .63 arasında, Artımsal Teori alt ölçeği için .33 ile .48 arasında sıralanmaktadır. Madde toplam korelasyonunun yorumlanmasında genellikle değeri .30 ve üzerinde olan maddeler ölçülecek özelliği ayırt etme açısından yeterli kabul edilmektedir (Büyüköztürk, 2010; Field, 2009; Özdamar, 2011). Buna göre, ölçeğin alt boyutlarına ilişkin madde toplam korelasyonlarının tutarlığının yeterli olduğu söylenebilir.

\section{Tartışma ve Sonuç}

Bu çalışmada Abd-El-Fattah ve Yates (2006) tarafından geliştirilen ÖZTÖ’nün Türk üniversite öğrencilerinde geçerlik ve güvenirliği incelenmiştir. ÖZTÖ’nün İngilizce ve Türkçe formlarının dilsel açıdan eşdeğer olup olmadığını tespit etmek için İngilizce ve Türkçe form arasındaki korelasyon hesaplanmıştır. Dilsel eşdeğerlik çalışmasından elde edilen bulgular, Türkçe ve orijinal form arasındaki korelasyonun oldukça yüksek olduğunu göstermiştir. Bu sonuç, ölçek maddelerinin Türkçe çevirisinin İngilizce formda yer alan orijinal maddelerle benzeştiğini ve Türkçe form ile İngilizce formun dilsel açıdan eş değer olduğunu göstermektedir.

Ölçeğin yapı geçerliğini incelemek amacıyla AFA ve DFA yapılmıştır. AFA sonucunda ÖZTÖ’nün orijinal formda olduğu gibi iki faktörlü bir yapıya sahip olduğu ve ölçek maddelerinin özgün formdaki maddelerle bire bir örtüştüğü belirlenmiştir. ÖZTÖ’nün alt boyutları toplam varyansın \%42.31'ini açıklamaktadır. AFA sonuçlarına göre, Varlık Teorisi alt boyutunda yer alan maddelerin faktör yükleri .61 ile .76 arasında değişmekte ve bu alt boyut toplam varyansın \%25.04'ünü açıklamaktadır. Artımsal Teori alt boyutunda yer alan maddelerin faktör yükleri .50 ile .67 arasında sıralanmakta ve bu alt boyut toplam varyansın \%17.27'sini açıklamaktadır. AFA'da açıklanan varyans oranı için \%30 ve üzerindeki değerlerin ölçüt olarak alındığı (Bayram, 2009; Büyüköztürk, 2010) ve ölçekte yer alan maddelere ait faktör yüklerinin .30 alt sınırının (Büyüköztürk, 2010; Costello \& Osborne, 2005; Martin \& Newell, 2004; Pallant, 2005; Schriesheim \& Eisenbach, 1995) üzerinde olduğu dikkate alındığında, ölçeğin yapı geçerliğinin sağlandığı söylenebilir. Ölçeğin özgün formunun Türk örneklemde doğrulanıp doğrulanmayacağını belirlemek üzere DFA yapılmıştır. DFA sonucunda elde edilen modelin uyum indeksi değerleri göz önüne alındığında, modelin uyumunun yeterli olduğu söylenebilir. 
ÖZTÖ’nün uyum geçerliğini ortaya koymak için ÖZTÖ ile BYÖ arasındaki korelasyon incelenmiştir. Elde edilen bulgular, varlık teorisinin performans-kaçınma ve performansyaklaşma yönelimi ile; artımsal teorinin öğrenme yönelimi ile pozitif anlamlı ilişki içersinde olduğunu göstermiştir. Zekâya ilişkin varlık teorisini benimseyen öğrencilerin daha çok performans yöneliminde; artımsal teoriyi benimseyen öğrencilerin ise daha çok öğrenme yöneliminde oldukları (Braten \& Strømsø, 2004; Dweck, 1991) dikkate alındığında, bu sonuçların örtük zeka teorisine ilişkin literatür ile örtüştüğü ortaya çıkmaktadır. Dolayısıyla ÖZTÖ ile BYÖ arasında hesaplanan korelasyonlar ölçeğin uyum geçerliği için bir kanıt olarak değerlendirilebilir.

ÖZTÖ’nün güvenirliğini belirlemeye yönelik olarak iç tutarlılık, test yarılama ve test tekrar test yöntemleri kullanılmıştır. İç tutarlılık güvenirlik katsayısı varlık teorisi alt ölçeği için .81 ve artımsal teori alt ölçeği için .71 olarak hesaplanmıştır. Test yarılama yöntemiyle hesaplanan güvenirlik katsayıları varlık teorisi alt ölçeği için .83 ve artımsal teori alt ölçeği için .71 şeklindedir. Test tekrar test yöntemi ile hesaplanan güvenirlik katsayıları ise, varlık teorisi alt ölçeği için .95 ve artımsal teori alt ölçeği için .90 olarak bulunmuştur. Güvenirlik katsayısı .70 ve üzerinde olan ölçeklerin güvenilir olduğu kabul edilmektedir (Anastasi, 1982; Domino \& Domino, 2006; Fraenkel, Wallend \& Hyun, 2012; Leech, Barlett \& Morgan, 2005; Nunnaly \& Bernstein, 1994; Pallant, 2005; Tezbaşaran, 1997). Buna göre, varlık teorisi ve artımsal teori alt ölçekleri için hesaplanan güvenirlik katsayılarının kabul edilebilir sınırlar içerisinde yer aldığı görülmektedir. ÖZTÖ için farklı güvenirlik hesaplama yöntemleri ile edilen güvenirlik katsayıları birbirleri ile karşılaştırıldığında, iç tutarlık ve test yarılama yöntemleri ile elde edilen güvenirlik katsayılarının birbirine benzer olduğu, buna karşın test tekrar test güvenirlik yöntemi ile bulunan güvenirlik katsayısının bu iki yöntem ile hesaplanan güvenirlik katsayısına göre daha yüksek olduğu görülmektedir. Test tekrar test yöntemi ile elde edilen güvenirlik katsayısının iç tutarlık ve test yarılama yöntemi ile hesaplanan güvenirlik katsayılarına göre daha yüksek olması, inançların değişime karşı direnç gösteren ve kısa sürede değişmesi mümkün olmayan yapılar (Nespor, 1987) olmasından kaynaklanıyor olabilir.

ÖZTÖ’de yer alan maddelerin toplam puanı yordama gücünü belirlemek ve ayırt edicilik düzeylerini saptamak amacıyla madde analizi yapılmıştır. Analiz sonucunda \%27'lik alt ve üst grupların madde puanlarındaki farklara ilişkin $\mathrm{t}$ değerlerlerinin, Varlık Teorisi alt ölçeği için 15.96 ile 25.95 arasında ( $\mathrm{sd}=202, \mathrm{p}<.001)$, Artımsal Teori alt ölçeği için 8.69 ile 14.22 arasında $(\mathrm{sd}=178, \mathrm{p}<.001)$ değiştiği saptanmıştır. Madde analizi sonucunda ayrıca, 
madde toplam korelasyonlarının; Varlık Teorisi alt ölçeği için .47 ile .63 arasında, Artımsal Teori alt ölçeği için .33 ile .48 arasında sıralandığı tespit edilmiştir. Madde toplam korelasyonunun yorumlanmasında genellikle değeri .30 ve üzerinde olan maddelerin ölçülecek özelliği ayırt etme açısından yeterli olduğu kabul edilmektedir (Büyüköztürk, 2010; Field, 2009; Özdamar, 2011). Buna göre, ölçeğin alt boyutlarına ilişkin madde toplam korelasyonlarının yeterli düzeyde olduğu söylenebilir.

Araştırmadan geçerlik, güvenirlik ve madde analizi ilgili elde edilen bulgular, ÖZTÖ’nün üniversite öğrencilerinin zekâya yönelik inançlarını ölçmede geçerli ve güvenilir bir araç olduğunu göstermektedir. Sonuç olarak, Abd-El-Fattah ve Yates (2006) tarafından geliştirilen ÖZTÖ’yü Türk Kültürüne kazandırmayı amaçlayan bu çalışma ile bireylerin zekanın doğası hakkındaki inançlarını ölçebilmede kullanılabilecek yeterli psikometrik özelliklere sahip bir ölçme aracına ulaşıldığı söylenebilir.

\section{Öneriler}

Alanyazın incelendiğinde, Türk kültüründe bireylerin zekaya yönelik inançlarını ölçmek amacıyla kullanılabilecek bir ölçme aracına rastlanmamıştır. Dolayısıyla, ÖZTÖ’nün Türkçe'ye uyarlandığı bu çalışmanın oldukça önemli olduğu düşünülmekte ve literatürdeki bu boşluğu dolduracağına inanılmaktadır. Öte yandan, bu uyarlama çalışmasının yalnızca üniversite öğrencilerinden oluşan bir çalışma grubu üzerinde yürütülmesi ölçeğin Türkçe formunun sadece üniversite öğrencilerinde geçerliği kanıtlanmış bir ölçme aracı olduğu anlamına gelebilir. Bu bağlamda, ölçeğin geçerlik ve güvenirliği için farklı örneklemler üzerinde yapılacak çalışmalar önem arz etmektedir.

ÖZTÖ’nün uyum geçerliği kapsamında, ÖZTÖ ile BYÖ arasındaki pearson momentler çarpımı korelasyonu hesaplanmıştır. Her birinde en az iki değişken bulunan iki veri seti arasındaki ilişkinin incelenmesinde, pearson momentler çarpımı korelasyonu yerine; kanonik korelasyon kullanmak değişken setleri arasında paylaşılan ortak varyansı ortaya koyabilir ve ölçme işlemine karışabilecek I. Tip hata kontrol altına tutarak daha güvenilir sonuçlar elde edilmesine imkan tanıyabilir (Stangor, 2010). Buna göre, ileri araştırmalarda, ÖZTÖ ile BYÖ arasındaki ilişkinin kanonik korelasyon analizi ya da yapısal eşitlik modeli gibi farklı yöntemler ile incelenmesi önerilebilir.

Örtük zekâ teorisine ilişkin alanyazın incelendiğinde, bireylerin zekâya yönelik inançlarının başarı yönelimleri ile birlikte öğrenme yaklaşımlarını (Dahl, Bals \& Turi, 2005; Stipek \& Gralinski, 1996; Vermetten, Lodewijks \& Vermunt, 2005 ), sınav kaygılarını (Cury, Elliot, Da Fonseca, \& Moller, 2006; Dweck \& Sorich, 1999; Stipek \& Gralinski, 1996) 
motivasyon kaynaklarını (Carr \& Dweck 2011; Dweck, 1986) ve risk alma davranışlarını (Dweck \& Leggett, 1988) etkilediği görülmektedir. Bu noktadan hareketle, ÖZTÖ ile öğrenme yaklaşımları, sınav kaygısı, motivasyon ve akademik risk alma davranışı arasındaki ilişkiyi belirlemeye yönelik ileri araştırmaların yapılması önerilebilir. ÖZTÖ’nün kullanılacağı ileri çalışmaların yapılması ölçeğin ölçme gücüne önemli katkılar sağlayacaktır.

\section{Kaynakça}

Abd-El-Fattah, S.M., \& Yates, G.C.R. (2006, November) Implicit Theory of Intelligence Scale: Testing for Factorial Invariance and Mean Structure. Paper presented at the Australian Association for Research in Education Conference, Adelaide, South Australia.

Ablard, K.E. (2002). Achievement Goals and Implicit Theories of Intelligence among Academically Talented Students. Journal for the Education of the Gifted, 25(3), 215232.

Ahmavaara, A. \& Houston, D.M. (2007). The Effects of Selective Schooling and SelfConcept on Adolescents' Academic Aspiration: An Examination of Dweck's Selftheory. British Journal of Educational Psychology, 77, 613-632.

Akbulut, Y. (2010). Sosyal Bilimlerde SPSS Uygulamaları. İstanbul: İdeal Kültür Yayıncılık. Akın, A. \& Çetin, B. (2007). Başarı Yönelimleri Ölçeği: Geçerlik ve Güvenirlik Çalışması. Eğitim Araştırmaları Dergisi, 26, 1-12.

Allison, J. A. \& Urdan, T. C. (1993, April). The Influence of Perceived Classroom Goals and Prior Beliefs on Aspects of Students' Motivation. Poster Session presented at the Annual Meeting of the American Educational Research Association, Atlanta, GA.

Ames, C. (1990). Motivation: What Teachers Need to Know? Teachers College Record, 91(3), 409-421.

Ames, C. (1992). Achievement Goals and Classroom Motivational Climate. In J. Meece and D. Schunk (Eds.). Students' Perceptions in the Classroom (pp. 327-348). Hillsdale, NJ: Erlbaum.

Ames, C. \& Archer, J. (1988). Achievement Goals in the Classroom: Students' Learning Strategies and Motivation Processes. Journal of Educational Psychology, 80(3), 260267.

Anastasi, A. (1982). Psychological Testing. New York: Mac Millan Publishing Co. Inc. 
Aronson, J., Fried, C. \& Good, C. (2002). Reducing the Effects of Stereotype Threat on African American College Students by Shaping Theories of Intelligence. Journal of Experimental Social Psychology, 38, 113-125.

Bayram, N. (2009). Sosyal Bilimlerde SPSS ile Veri Analizi. Bursa: Ezgi Kitabevi.

Beaton, D.E., Bombardier, C., Guillemin, F. \& Ferraz, M.B. (2000). Guidelines for the Process of Cross-Cultural Adaptation of Self-Report Measures. Spine, 25(24), 31863191.

Bempechat, J., London, P. \& Dweck, C.S. (1991). Children's Conceptions of Ability in Major Domains: An Interview and Experimental Study. Child Study Journal, 21(1), 11-36.

Bentler, P.M. (1980). Multivariate Analysis with Latent Variables: Causal Modeling. Annual Review of Psychology, 31, 419-456.

Bentler, P.M. \& Bonett, D.G. (1980). Significance Tests and Goodness of Fit in the Analysis of Covariance Structures. Psychological Bulletin, 88, 588-606.

Blackwell, L.S. (2002). Psychological Mediators of Student Achievement During the Transition to Junior High School: The Role of Implicit Theories. Unpublished Doctoral Dissertation, Columbia University, New York

Blackwell, L.S., Trzesniewski, K.H. \& Dweck, C.S. (2007). Implicit Theories of Intelligence Predict Achievement across an Adolescent Transition: A Longitudinal Study and an Intervention. Child Development, 78(1), 246-263.

Bråten, I. \& Stromso, H.I. (2004). Epistemological Beliefs and Implicit Theories of Intelligence as Predictors of Achievement Goals. Contemporary Educational Psychology 29(4), 371-388.

Brown, M. \& Cudeck, R. (1993). Alternative Ways of Assessing model Fit. In: K. Bollen \& J. Long, (Eds), Testing Structural Equation Models (pp. 136-162). London: Sage Publications.

Bryman, A. \& Cramer, D. (2001). Quantitative Data Analysis with SPSS Release 10 for Windows. London: Routledge.

Büyüköztürk, Ş. (2010). Sosyal Bilimler İçin Veri Analizi El Kitabı. Ankara: Pegem Akademi Yayınları.

Byrne, B. \& Campbell, T.L. (1999). Cross-cultural Comparisons and the Presumption of Equivalent Measurement and Theoretical Structure: A Look Beneath the Surface. Journal of Cross-Cultural Psychology, 30(5), 555-574.

Byrne, B.M. (2010). Structural Equation Modeling with AMOS: Basic Concepts, Applications and Programming. New York, NY: Taylor and Francis Group. 
Cadwallader, S.M. (2009). The Implicit Theories of Intelligence of English Adolescents Identified as Gifted and Talented. Unpublieshed Doctoral Dissertation, University of Warwick.

Carr, P.B. \& Dweck, C.S. (2011). Intelligence and Motivation. In R.J. Sternberg and S.B. Kaufman (Eds.), The Cambridge Handbook of Intelligence (pp. 748-70). New York, NY: Cambridge University Press.

Cattell, R.B. (1978). The Scientific Use of Factor Analysis in Behavioral and Life Sciences. New York: Plenum.

Chiu, C.Y., Hong, Y.Y. \& Dweck, C.S. (1997). Lay Dispositionism and Implicit Theories of Personality. Journal of Personality and Social Psychology, 73(1), 19-30.

Costello, A.B. \& Osborne, J.W. (2005). Best Practices in Exploratory Factor Analysis: Four Recommendations for Getting the Most from Your Analysis. Practical Assessment Research \& Evaluation, 10(7), 1-9.

Cramer, D. (2003). Advanced Quantitative Data Analysis. Philadelphia: McGraw-Hill Education.

Cury, F., Elliot, A., Da Fonseca, D. \& Moller, A.C. (2006). The Social Cognitive Model of Achievement Motivation and the $2 * 2$ Achievement Goal Framework. Journal of Personality and Social Psychology, 90, 666-679.

Çokluk, Ö., Şekercioğlu, G. \& Büyüköztürk, Ş. (2012). Sosyal Bilimler için Çok Değişkenli İstatistik: SPSS ve LISREL Uygulamalart. Ankara: Pegem Akademi Yayınc1lık.

Da Fonseca, D., Cury, F., Bailly, D., \& Rufo, M. (2004). Role of the Implicit Theories of Intelligence in Learning Situations. Encephale, 30(5), 456-463.

Da Fonseca D, Schiano-Lomoriello S, Cury F, Poinso F, Rufo M \& Therme P. (2007). Validation Study of the Implicit Theories Of İntelligence Scale. Encephale, 33, 579-84.

Dahl, T.I., Bals, M. \& Turi, A.L. (2005). Are Students' Beliefs about Knowledge and Learning Associated with Their Reported Use of Learning Strategies? British Journal of Educational Psychology, 75, 257-273.

Delavar, A., Ahadi, H. \& Barzegar, M. (2011, August). Relationship Between Implicit Theory of Intelligence, 2*2 Achievement Goals Framework, Self-Regulating Learning with Academic Achievement. A Verbal Report in the 2nd International Conference on Education and Management Technology, Shanghai, China.

Deryakulu, D. (2006). Epistemolojik İnançlar. Y. Kuzgun ve D. Deryakulu, (Ed.), Eğitimde Bireysel Farklılıklar içinde (261-289). Ankara: Nobel Yayın Dağıtım. 
Diener, C.I., \& Dweck, C.S. (1980). An analysis of Learned Helplessness: II. The Processing of Success. Journal of Personality and Social Psychology, 39(5), 940-952.

Domino, G. \& Domino, M.L. (2006). Psychological Testing: An Introduction. Cambridge: Cambridge University Press.

Dweck, C.S. (1986). Motivational Processes Affecting Learning. American Psychologist, 41(10), 1040-1048.

Dweck, C.S. (1991). Self-theories and Goals: Their Role in Motivation, Personality and Development. In R. Dienstbier (Eds.), Nebraska Symposium on motivation. Lincoln, Nebraska: University of Nebraska Press.

Dweck, C.S. (1999). Self-Theories: Their Role in Motivation, Personality, and Development. Philadelphia, PA: Taylor \& Francis

Dweck, C.S. \& Bempechat, J. (1983). Children's theories of intelligence. In S. Paris, G. Olsen \& H. Stevenson (Eds.), Learning and Motivation in the Classroom (pp. 239-256). Hillsdale, NJ: Erlbaum.

Dweck, C.S., Chiu, C. \& Hong, Y. (1995). Implicit Theories and Their Role in Judgments and Reactions: A World from Two Perspectives. Psychological Inquiry, 6(4), 267-285.

Dweck, C.S. \& Henderson, V.L. (1989). Theories of intelligence: Background and Measures. Paper Presented at the Biennial Meeting of the Society for Research in Child Development, Kansas City, MO.

Dweck, C.S., Hong, Y.Y. \& Chiu, C.Y. (1993) Implicit theories and Individual Differences in the Likelihood an and Meaning of Dispositional Inference. Personality and Social Psychology Bulletin, 19(5), 644-656.

Dweck, C.S. \& Leggett, E.L. (1988). A Social-Cognitive Approach to Motivation and Personality. Psychological Review, 95(2), 256-273.

Dweck, C.S. \& Master, A. (2008). Self-theories Motivate Self-Regulated Learning. In D. Schunk \& B. Zimmerman (Eds). Motivation and Self-Regulated Learning: Theory, Research, and Applications (pp. 31-51). Mahwah, NJ: Erlbaum.

Dweck, C.S., \& Molden, D.C. (2005). Self-Theories: Their Impact on Competence and Acquisition. In A. Elliot, \& C.S. Dweck (Eds.), The Handbook of Competence and Motivation (pp. 122-140). NY: Guilford Press.

Dweck, C.S. \& Sorich, L.A. (1999). Mastery-Oriented Thinking. In C.R. Snyder (Eds.), Coping the Psychology Works-The Psychology of What Works. New York: Oxford University Press. 
Dupeyrat, C. \& Mariné, C. (2005). Implicit Theories of Intelligence, Goal Orientation, Cognitive Engagement, and Achievement: A Test of Dweck's Model with Returning to School Adults. Contemporary Educational Psychology, 30(1), 43-59.

Elliot, A.J. \& Church, M.A. (1997). A Hierarchical Model of Approach and Avoidance Motivation. Journal of Personality and Social Psychology, 72, 218-232.

Ferguson, E. \& Cox, T. (1993). Exploratory Factor Analysis: A Users' Guide. International Journal of Selection and Assessment, 1(2), 84-94.

Field, A. (2009). Discovering Statics Using SPSS. London: SAGE Publications Ltd.

Fishbein, M. \& Ajzen, I. (1975). Belief, Attitude, Intention and Behavior: An Introduction to Theory and Research. Reading, MA: Addison-Wesley.

Fraenkel, J.R., Wallend, N.E. \& Hyun, H.H. (2012). How to Design and Evaluate Research in Education. New York: McGraw Hill.

Garcia-Cepero, M.C. \& McCoach, D.B. (2009). Educators Implicit Theories of Intelligence and Beliefs about the Identification of Gifted Students. Universitas Psychologica, 8(2), 295-310.

Geisinger, K.F. (1994). Cross-Cultural Normative Assessment: Translation and Adaptation Issues Influencing the Normative Interpretation of Assessment Instruments. Psychol Assess, 6(4), 304-312.

Gervey, B., Chiu, C., Hong, Y. \& Dweck, C.S. (1999). Differential Use of Person Information in Decision-Making about Guilt Versus Innocence: The role of Implicit Theories. Personality and Social Psychology Bulletin, 25(1), 17-27.

Good, C., Aronson, J. \& Inzlicht, M. (2003). Improving Adolescents' Standardized Test Performance: An Intervention to Reduce the Effects of Stereotype Threat. Journal of Applied Developmental Psychology, 24(6), 645 - 662.

Goetz, T.E. \& Dweck, C.S. (1980). Learned Helplessness in Social Situations. Journal of Personality and Social Psychology, 39(2), 246-255.

Hair, J.F., Anderson, R.E., Tatham, R.L. \& Grablowsky, B.J. (1979). Multivariate Data Analysis. Tulsa, OK: Pipe Books.

Hambleton, R.K. \& Bollwark, J. (1991) Adapting Tests for Use in Different Cultures: Technical Issues and Methods. Bulletin of the International Test Commission, 18, 3-32.

Hambleton, R.K., \& Kanjee, A. (1993, April). Enhancing the Validity of Cross-Cultural Studies: Improvements in Instrument Translation Methods. Paper presented at the Annual Meeting of the American Educational Research Association, Atlanta, GA. 
Hazır B.F. (2002). Fen Öğretiminde Öz Yeterlilik İnanc1. Eğitim Bilimleri ve Uygulama, 1(2), 197-2010.

Henderson, V. \& Dweck, C.S. (1990). Motivation and Achievement. In S.S. Feldman \& G.R. Elliot (Eds.), The Developing Adolescent (pp. 308-329). Cambridge, MA: Harvard University Press.

Hofstede, G. (2001). Culture's Consequences: Comparing Values, Behaviors, Institutions, and Organizations Across Nations. NY: Sage Publications, Inc.

Hong, Y.Y, Chiu, C. \& Dweck, C.S. (1995). Implicit theories of Intelligence: Reconsidering the Role of Confidence in Achievement Motivation. In M. Kernis (Eds.), Efficacy, Agency and Self-Esteem (pp. 197-216). New York: Plenum.

Hong, Y.Y. Dweck, C.S. \& Chiu, C. (1999). Implicit Theories, Attributions, and Coping: A Meaning System Approach. Journal of Personality and Social Psychology, 77(3), 588599.

Hu, L.T., \& Bentler, P.M. (1999). Cutoff Criteria for Fit Indexes in Covariance Structural Analysis: Conventional Criteria Versus New Alternatives. Structural Equation Modeling, 6, 1-55.

Husman, J., Hilpert, J., Stump, G. \& Lynch, C. (2009). From Thinking about the Future to Achieving in the Present: A Study of Postsecondary Science and Engineering Courses. Unpublished Manuscript, Arizona State University, Arizona.

Hutcheson, G. \& Sofroniou, N. (1999). The Multivariate Social Scientist. London: Sage.

Kennett, J.D. \& Keefer, K. (2006). Impact of Learned Resourcefulness and Theories of Intelligence on Academic Achievement of University Students: An Integrated Approach. Educational Psychology, 26(3), 441-457.

Kline, R.B. (1994). An Easy Guide to Factor Analysis. New York: Routledge.

Knee, C.R. (1998). Implicit Theories of Relationships: Assessment and Prediction of Romantic relationship Initiation, Coping and Longevity. Journal of Personality and Social Psychology, 74(2), 360-370.

Knee, C.R., Nanayakkara, A., Vietor, N.A., Neighbors, C. \& Patrick, H. (2001). Implicit theories of relationships: Who Cares If Romantic Partners are Less than ideal? Personality and Social Psychology Bulletin, 27(7), 808-819.

Koballa, T.R. \& Crowley, F.E. (1985). The Influence of Attitude on Science Teaching and Learning. School Science and Mathematics, 85(3), 222-232. 
Krows, A.J. (1999). Preservice Teachers' Belief Systems and Attitudes Toward Mathematics in the Context of a Progressive Elementary Teacher Preparation Program. Unpublished Doctoral Dissertations. The University of Oklohama. Norman, Oklohoma.

Lee, K. (1996). A Study of Teacher Responses Based on Their Conceptions of Intelligence. Journal of Classroom Interaction, 31(2), 1-12.

Leech, N.L. Barlett, K.C. \& Morgan, G.A. (2005). SPSS for Intermediate Statistics; Use and Interpretation. Mahwah, NJ: Lawrence Erlbaum Associates.

Leondari, A. \& Gialamas, V. (2002). Implicit Theories, Goal Orientations, and Perceived Competence: Impact on Students' Achievement Behavior. Psychology in the Schools. 39(3), 279-291.

Lim, W., Plucker, J.A. \& Kyuhueok, Im. (2002). We are More Alike than We Think We are Implicit Theories of Intelligence with a Korean Sample. Intelligence, 30 (2), 185-208.

Maneesriwongul, W., \& Dixon, J.K. (2004). Instrument Translation Process: A Methods Review. Journal of Advanced Nursing Research, 48(2), 175-186.

Mangels, J.A., Butterfield, B., Lamb, J., Good, C. \& Dweck, C.S. (2006). Why Do Beliefs about Intelligence Influence Learning Success? A Social Cognitive Neuroscience Model. Social, Cognitive and Affective Neuroscience, 1(2), 75-86.

Mansour, N. (2009). Science Teachers' Beliefs and Practices: Issues, Implications and Research Agenda. International Journal of Environmental \& Science Education, 4(1), $25-48$.

Marsh, H.W., Hau, K.T., Artelt, C., Baumert, J. \& Peschar, J.L. (2006). OECD’s Brief SelfReport Measure of Educational Psychology's Most Useful Affective Constructs: Crosscultural, Psychometric Comparisons across 25 Countries. International Journal of Testing, 6(4), 311-360.

Martin, C.R. \& Newell, R.J. (2004). Factor Structure of the Hospital Anxiety and Depression Scale in Individuals with Facial Disfigurement. Psychology Health and Medicine, 9(3), 327-336.

Meydan, C.H. \& Şeşen, H. (2011). Yapısal Eşitlik Modellemesi ve AMOS Uygulamaları. Ankara: Detay Yayıncılık

Mueller, C.M. \& Dweck, C.S. (1998). Praise for Intelligence Can Undermine Children. Journal of Personality and Social Psychology, 75(1), 33-52.

Nespor, J. (1987). The Role of Beliefs in the Practice of Teaching. Journal of Curriculum Studies, 19, 317-328. 
Nunnaly, J. \& Bernstein, I. (1994). Psychometric Theory. New York: McGraw-Hill.

Olson, J.M., Roese, N.J. \& Zanna, M.P. (1996). Expectancies. In E.T. Higgins \& A.W. Kruglanski (Eds.), Social Psychology: Handbook of Basic Principles (pp. 211-238). New York: Guilford Press.

Özdamar, K. (2011). Paket Programları ile Ístatistiksel Veri Analizi-I. Eskişehir: Kaan Kitabevi.

Öztuna Kaplan, A. \& Macaroğlu Akgül, M. (2009). Prospective Elemantary Science Teachers' Epistemological Beliefs. Procedia Social and Behavioral Sciences, 25292533.

Pajares, F. (1992). Teachers' Beliefs and Educational Research: Cleaning up a Messy Construct. Review of Educational Research, 62(3), 307-332.

Pallant, J. (2005). SPSS Survival Manual: A Step by Step Guide to Data Analysis Using SPSS for Windows. Australia: Australian Copyright.

Pintrich, P.R. \& Schunk, D.H. (2002). Motivation in Education: Theory, Research and Applications. Upper Saddle River, NJ: Merrill Prentice Hall.

Plaks, J.E, Grant, H. \& Dweck, C.S. (2005). Violations of Implicit Theories and the Sense of Prediction and Control: Implications for Motivated Person Perception. Journal of Personality and Social Psychology, 88(2), 245-262.

Pressley, M., \& Harris, K.R. (2008). Cognitive Strategies Instruction: From Basic Research to Classroom Instruction. In P.A. Alexander and P.H. Winne (Eds.), Handbook of Educational Psychology (pp. 265-286). Mahwah: Lawrence Erlbaum Associates.

Richardson, V. (2003). Pre-Service Teachers' Beliefs. In J. Raths \& A. C. McAninch (Eds.), Teacher Beliefs and Classroom Performance: The Impact of Teacher Education (pp. 122). Greenwich, CT: Information Age Publishing.

Robins, R. W. \& Pals, J. L. (2002). Implicit Self-Theories in the Academic Domain: Implications for Goal Orientation, Attributions, Affect and self-esteem Change. Self and Identity, 1(4), 313-336.

Roedel, T.D. \& Schraw, G. (1995). Beliefs about Intelligence and Academic Goals. Contemporary Educational Psychology, 20(4), 464-468.

Schermelleh-Engel, K. \& Moosbrugger, H. (2003). Evaluating the Fit of Structural Equation Models: Tests of Significance and Descriptive Goodness-of-Fit Measures. Methods of Psychological Research Online, 8(2), 23-74.

Schommer, M. (1998). The Influence of Age and Education on Epistemological Beliefs. British Journal of Educational Psychology, 68(4), 551-562. 
Schriesheim, C.A. \& Eisenbach, R.J. (1995). An Exploratory and Confirmatory Factor Analytic Investigation of Item Wording effects on Obtained Factor Structures of Survey Questionnaire Measures. Journal of Management, 21(6), 1177-1193.

Sipahi, B., Yurtkoru, S. ve Çinko, M. (2010). Sosyal Bilimlerde SPSS'le Veri Analizi. İstanbul: Beta Basım Yayım Dağıtım.

Sorich-Blackwell, L. (2001). Theories of Intelligence Predict Motivation and Achievement across the Adolescent Transition. Unpublished Doctoral Dissertation, Columbia University.

Spinath, B., Spinath, F., Riemann,R. \& Angleitner, A. (2003). Implicit Theories about Personality and Intelligence and Their Relationship to Actual Personality and Intelligence. Personality and Individual Differences, 35(4), 939-951.

Stangor, C. (2010). Research Methods for the Behavioral Sciences. Wadsworth.

Stipek, D. \& Gralinski, J.H. (1996). Children's Beliefs about Intelligence and School Performance. Journal of Educational Psychology, 88(3), 397-407.

Tezbaşaran, A. (1997). Likert Tipi Ölçek Hazırlama Kılavuzu. Ankara: Türk Psikologlar Derneği.

Vandewalle, D. (1997). Development and Validation of a Work Domain Goal Orientation Instrument. Educational and Psychological Measurement, 57(6), 995-1015.

Vermetten, Y.J., Lodewijks, H.G. \& J.D. Vermunt. (2001). The Role of Personality Traits and Goal Orientations in Strategy Use. Contemporary Educational Psychology, 26(2), 149170.

Ziegler, A., Schober, B. \& Dresel, M. (2005). Primary School Students' Implicit Theories of Intelligence and Maladaptive Behavioral Patterns. Georgian Electronic Scientific Journal: Education Science and Psychology, 1(6), 76-86. 